(c) <2021 > . This manuscript version is made available under the CC-BY-NC-ND 4.0 license http://creativecommons.org/licenses/by-nc-nd/4.0/

The definitive publisher version is available online at https://doi.org/ 10.1016/.geotexmem.2021.05.004 


\title{
The Role of Geosynthetics in Reducing the Fluidisation Potential of Soft Subgrade under Cyclic Loading
}

\author{
Joseph Arivalagan ${ }^{1}$; Cholachat Rujikiatkamjorn, Ph.D. ${ }^{2}$; Buddhima Indraratna, Ph.D., \\ F.ASCE ${ }^{3}$; Andy Warwick ${ }^{4}$ \\ ${ }^{1} \mathrm{PhD}$ student, \\ School of Civil \& Environmental Engineering, University of Technology Sydney, NSW 2007 \\ ARC Industrial Transformation Training Centre, ITTC-Rail, \\ University of Wollongong, Wollongong City, NSW 2522, Australia. \\ Email: Joseph.Arivalagan@student.uts.edu.au
}

${ }^{2}$ Professor, School of Civil \& Environmental

Engineering, University of Technology Sydney, NSW 2007.

Email: Cholachat.Rujikiatkamjorn@uts.edu.au

${ }^{3}$ Distinguished Professor and Director, Transport Research Centre

University of Technology Sydney, NSW 2007, Australia.

Email: buddhima.indraratna@uts.edu.au, Ph: +61 400213046

\author{
${ }^{4}$ National Sales and Marketing Manager, \\ Polyfabrics Australasia Pty Ltd, Australia. \\ Email: awarwick@polyfabrics.com.au
}

$\uparrow$ Author for correspondence:
Distinguished Prof. Buddhima Indraratna
Director, Transport Research Centre,
University of Technology Sydney
Email: buddhima.indraratna@uts.edu.au

Submitted to: Geotextiles and Geomembranes 


\section{ABSTRACT}

2 The instability of railway tracks including mud pumping, ballast degradation, and differential settlement 3 on weak subgrade soils occurs due to cyclic stress from heavy haul trains. Although geotextiles are 4 currently being used as a separator in railway and highway embankments, their ability to prevent the 5 migration of fine particles and reduce cyclic pore pressure has to be investigated under adverse 6 hydraulic conditions to prevent substructure failures. This study primarily focuses on using 7 geosynthetics to mitigate the migration of fine particles and the accumulation of excess pore pressure 8 (EPP) due to mud pumping (subgrade fluidisation) using dynamic filtration apparatus. The role that 9 geosynthetics play in controlling and preventing mud pumping is analysed by assessing the 10 development of EPP, the change in particle size distribution and the water content of subgrade soil.

11 Using 3 types of geotextiles, the potential for fluidisation is assessed by analysing the time-dependent excess pore pressure gradient (EPPG) inside the subgrade. The experimental results are then used to evaluate the performance of selected geotextiles under heavy haul loading. gradient 
Since the demand for safe and resilient rail tracks for faster and heavier traffic has been growing steadily over the past decades, so too have ongoing improvements to increase track capacity and reduce maintenance costs. The performance of railway substructure is greatly affected by dynamic stresses caused by axle loads and the speed of freight trains. Under repeated cyclic loading, the samples can become unstable under the applied stress well below the undrained static shear strength (Indraratna et al. 2020c). Without appropriate drainage, cyclic loading can cause undrained shear failure of the soft subgrade and also induce localised 'mud pumping' that will result to a serious loss of stiffness and fouling of the track. Ballast mixed with pumped-up mud fines (fouled ballast) can result in excessive deformation and localised failure under undrained condition due to the reduction of its overall drainage properties, shear strength and resilient modulus (Tennakoon \& Indraratna 2014). Nguyen \& Indraratna (2021) found that when the fouling index exceeds $30 \%$, the drainage capacity of the track can be insufficient considering a significant rainfall event ( $>67.5 \mathrm{~mm} /$ hour $)$. Ballast particle movement at mud pumping locations can be considered to identify the problematic railway tracks (Liu et al. 2019). Remediation techniques and frequent maintenance are then needed to stabilise railway tracks to ensure safe and effective operations (Arulrajah et al. 2009; Hudson et al. 2016; Wheeler et al. 2017).

According to Nguyen et al. (2019), saturated subgrade soil in low lying areas becomes internally unstable and begins to pump up to the ballast layer due to the excessive upward hydraulic gradient induced by an increase in excess pore water pressure (EPP) at shallow depths. Under cyclic loading conditions the Cyclic Stress Ratio (CSR), the frequency (f), and the characteristics of subgrade such as the consistency and degree of compaction of soil, are among the key factors which lead to mud pumping in railway tracks (Indraratna et al. 2020c). The repetitive train loading can develop EPP and excessive seepage velocity in the subgrade, thus leading to fluidization of shallow soil layers and the loss of fines from the subgrade soil (Hayashi \& Shahu 2000). The increased cyclic load can intensify the occurrence of subgrade fluidization with interlayer mixing due to the penetration of sub-ballast (gravel) into the softened subgrade (Zhang et al. 2021). Indeed, a rapid generation in EPP can lead to a sharp drop in the mean effective stress and thus initiate subgrade fluidisation (mud pumping) and/or shear failure. 
Although the undrained instability of subgrade soil has been addressed in previous studies, further investigation is required under free drainage conditions that represent more realistic railway track environments.

Experimental investigations to study the factors affecting subgrade fluidisation have been carried out in previous studies (Duong et al. 2014; Indraratna et al. 2020a; Indraratna et al. 2020b). The key factors contributing to mud pumping are the in-situ hydraulic gradients and the amount of erodible fines present in the subgrade. The difference in pore pressure between two locations generates the hydraulic uplift to facilitate migration of these fine particles (Yu et al. 2016). When the hydraulic gradient exceeds the critical hydraulic gradient, the finer particles begin to displace significantly to induce instability of the subgrade (Indraratna et al. 2021).

Mud pumping and the migration of fine particles can be controlled by installing a compacted capping layer and placing appropriate drainage geotextiles in the track substructure (Feng et al. 2019). Together they can provide sufficient drainage and load-carrying capacity which can prevent subgrade yielding by alleviating excessive hydraulic gradients (Moffat \& Herrera 2015; Sabiri et al. 2020). Israr \& Indraratna (2017) have already analysed the internal instability of compacted granular soils under static and cyclic loading conditions as well as effectiveness of granular filters by measuring the amount of eroded fine particles and observing failures such as internal suffusion and subsequent piping failure. The geosynthetics can be applied to highway embankments and railway tracks to improve strength, stiffness and load bearing capacity of weak subgrade soils (Arulrajah et al. 2015; Rajagopal 2017; Rajagopal et al. 2014). While certain geosynthetics can mitigate the migration of fines in typical rigid pavements and track foundations (Kermani et al. 2020), several studies and field investigations confirm that surface drainage via geotextiles can help to prevent subgrade erosion, limit excessive deformation and mud pumping under heavy haul loading (Aw 2007; Kermani et al. 2018; Selig \& Waters 1994).

Design guidelines for the use of geotextiles under rail tracks have been proposed as common filtration design elements by incorporating permeability and retention criteria while addressing the durability and instability of subgrade, and survivability issues (Ayres 1986; Luettich et al. 1992). Characteristics of filtration and permeability depend mainly on the pore opening sizes of geotextiles, and the filtration 
opening sizes may vary under tension and confinement. The pore dimensions of nonwoven geotextile mainly rely on the manufacturing process, fibrous material distributions, shape of fiber and intertwinement (Palmeira et al. 2019). Dry and wet sieving, hydrodynamic sieving, mercury intrusion porosimetry, image analysis, and bubble point methods are commonly used to evaluate the pore size distribution of geotextiles (Aydilek et al. 2002; Bhatia \& Smith 1996); the different methods used to define soil and geotextile filtration, retention, and clogging criteria have also been studied earlier (Bhatia \& Huang 1995; Faure et al. 2006; Ghataora et al. 2006; Ghosh \& Yasuhara 2004; Palmeira et al. 1997; Palmeira 2009; Xiao \& Reddi 2000). The Gradient Ratio (GR) and Hydraulic Conductivity Ratio (HCR) are the common methods used to determine the permeability, hydraulic conductivity, and filtration capacity of geotextiles (Khan et al. 2018; Palmeira \& Gardoni 2000; Williams \& Abouzakhm 1989). To evaluate the filtration of soil geotextile systems, the GR method is mainly used to describe the relationship between the hydraulic gradient across the soil geotextile interface and the hydraulic gradient that develops within the soil.

Cyclic tests were carried out on a full-panel railway track model where geosynthetics are commonly used to reinforce the track and mitigate mud pumping (Chawla \& Shahu 2016). The filtrameter used to measure the retention capability of geotextile/soil filter system revealed that the formation of a bridging network within the base soil through the geotextile would not necessarily provide stable filtration (Bhatia \& Huang 1995). This is because any change in the hydraulic gradient can collapse the bridging network and filtration process, and subsequently lead to instability in the subgrade soil. Small scale equipment under cyclic triaxial conditions was used to simulate unit cells to measure changes in the EPP and also determine how geotextile in highway embankments can control the rate at which fine particles are pumped (Alobaidi \& Hoare 1994; Alobaidi \& Hoare 1998; Alobaidi \& Hoare 1996). The rate of pumping through the geotextile, the development of pore water pressure in the subgrade, and the creation of an interlayer at the interface have been addressed for highway embankments. Anti-pumping geosynthetics should have a high compression modulus to prevent a larger hydraulic gradient from being generated below the loaded area and also provide sufficient permeability over the long term 
(Alobaidi \& Hoare 1999). The pore water pressure contours show that the subgrade soil beneath the interface is the most vulnerable and the rate of mud pumping can increase by applying moving loads.

The main focus of this study is to evaluate how well the geotextiles placed in weak subgrade soil can alleviate the development of excess pore water pressure and prevent particles from migrating across the soil/geotextile interface. To study the inception of subgrade fluidisation and the role of geotextiles, large scale dynamic filtration tests were carried out to simulate the in-situ hydraulic conditions in railway tracks and assess how effective track substructures/geosynthetics are in terms of filtration and drainage. The effects of the loading characteristics on the performance of geosynthetics have also been evaluated under typical rail track conditions.

\section{EXPERIMENTAL PROGRAM}

\subsection{Testing Material}

Disturbed subgrade soil was collected from a rail track at Wollongong (NSW, Australia) that was experiencing mud pumping. Basic geotechnical tests such as the Atterberg Limit (ASTM D4318-00 2003), particle size distribution (ASTM D422-63 2007), permeability (ASTM D5856-95 2002), Proctor compaction (ASTM D698-00 2000) and specific gravity (ASTM D854-02 2002) were then carried out on samples of this soil. Falling head tests (ASTM D4491-99 1999) were also carried out on geotextiles because their permittivity is less than $0.05 \mathrm{sec}^{-1}$. The liquid limit (LL) and plastic limit (PL) are 42\% and $26 \%$, respectively. Figure 1 (a) and 1(b) show the soil properties at various mud pumping sites (Alobaidi \& Hoare 1996; Ayres 1986; Boomintahan \& Srinivasan 1988; Chawla \& Shahu 2016; Duong et al. 2014; Indraratna et al. 2020c; Kuo et al. 2017; Liu et al. 2013; Muramoto et al. 2006; Raymond 1986; Trinh et al. 2012; Voottipruex \& Roongthanee 2003). According to the Unified Soil Classification System, this soil could be classified as inorganic clay with medium plasticity. The maximum dry density and optimum moisture content were obtained using the standard Proctor test (ASTM D698-00 2000), and they are $1682 \mathrm{~kg} / \mathrm{m}^{3}$ and $18.5 \%$, respectively. An in-situ soil density of $1600 \mathrm{~kg} / \mathrm{m}^{3}$ is used for the 
laboratory experiments because it corresponds to a relative compaction (RC) of $95 \%$. The permeability of compacted soil of $8.9 \times 10^{-7} \mathrm{~m} / \mathrm{s}$ was determined using the falling head method.

The fresh ballast material commonly used in New South Wales (NSW) tracks were adopted in this study. The physical properties of the ballast were provided in elsewhere by Indraratna et al. (1998). The maximum and mean particle sizes were $37.5 \mathrm{~mm}$ and $30 \mathrm{~mm}$ respectively.

Three types of geotextiles with different size pore openings were chosen. The geocomposite G1 had a filter media in between nonwoven geotextile layers with a filter's aperture opening size $\left(\mathrm{O}_{95}\right)$ of $<1 \mu \mathrm{m}$, whereas $\mathrm{O}_{95}$ of $\mathrm{G} 2$ and $\mathrm{G} 3$ were 60 and $75 \mu \mathrm{m}$ respectively (ASTM F316-03 2011). The tensile strength of G1, G2, and G3 follows EN ISO 10319 (2008) and are 50, 52.5 and 30 kN/m respectively. G1, G2, and G3 have a maximum CBR puncture resistance of $10 \mathrm{kN}, 9 \mathrm{kN}$ and $5 \mathrm{kN}$ respectively (EN ISO 12236 2006). All the properties of the geotextiles are listed in Table 1 (Fiberweb 2012).

\subsection{Dynamic filtration tests}

The filtration apparatus developed by Israr et al. (2016) has been modified to monitor the local EPP, soil porosity, and deformation as cyclic loads are applied. As Figure 2(a) shows, the apparatus has ten components, (1) Load cell and linear variable differential transformer (LVDT), (2) Miniature pore pressure transducers (MPs), (3) Body pressure transducers (Ps), (4) Amplitude Domain Reflectometry Probes (ADRs), (5) Datalogger, (6) Computer (7) Camera (8) Power supply, (9) Inlet for saturating the sample from a de-aired tank, and (10) Hydraulic actuator. The load cell actuator can apply a vertical monotonic or cyclic load up to $40 \mathrm{kN}$ with a frequency up to $40 \mathrm{~Hz}$, through the piston connected to the loading plate.

The polycarbonate glass cell has a $240 \mathrm{~mm}$ internal diameter, and it is $300 \mathrm{~mm}$ high and $13 \mathrm{~mm}$ thick. Its internal wall is coated with Teflon to minimise friction between the surface and soil particles. During the design of this equipment, it was checked that the radial relaxation was relatively small (less than $5 \times 10^{-4} \mathrm{~mm}$ ) for the lateral pressure induced by applied cyclic loading based on Young's modulus of the 
$15713 \mathrm{~mm}$ thick shell $(\mathrm{E}=2.6 \mathrm{GPa})$. The ratio between the largest particle to the internal diameter of the 158 cell is less than 1/6 to minimise boundary effects (ASTM D3999-91 2003). There are four miniature 159 pore pressure transducers (1 $\mathrm{kPa}$ accuracy) at the centreline of the soil specimen $20,40,80$, and 120 $\mathrm{mm}$ from the top ballast/subgrade interface. At the edge, there are six body transducers $(0.5 \mathrm{kPa}$ accuracy) at 25, 55, 85, 115, 145, and $175 \mathrm{~mm}$ from the ballast/subgrade interface, as shown in Figure 2(b). A linear variable differential transformer (LVDT) is built into the hydraulic actuator to capture the total axial compression of a sample. A $50 \mathrm{~mm}$ diameter load cell is attached to the bottom of the test chamber to monitor vertical stress.

\subsection{Test procedures}

The test procedures consisted of: (1) compaction, (2) saturation, (3) consolidation, (4) interface preparation, and (5) a loading application. The mass of dry soil and the volume of water needed were mixed beforehand and left overnight in the humidity controlled room and then compacted inside the test chamber in eight layers. The target bulk density $\left(1600 \mathrm{~kg} / \mathrm{m}^{3}\right)$ and moisture content $(17 \%)$ were attained by compacting the dry soil and water to the desired volume. The nonlinear undercompaction criterion proposed by Jiang et al. (2003) was employed to achieve uniform density of test specimens. As proposed by Indraratna et al. (2020c), the required height of each layer was calculated using the average predetermined thickness of an individual layer. After compaction, the uniformity of each specimen was also assessed by coring additional samples to measure their overall dry density, and the dry density of each layer. The uniformity of each specimen was assessed by preparing additional samples and then measuring, (a) their overall dry density, and (b) the dry density of each layer. Saturation was carried out in two steps (1) de-airing the sample by applying $100 \mathrm{kPa}$ of suction (Kamruzzaman et al. 2008), and (2) filling the cell with filtered and de-aired water until the water level reached the top of the specimens. The saturation of this specimen was monitored by three ADR probes installed at different depths (Israr et al. 2016; Trani \& Indraratna 2010); these probes remain in situ until uniform readings are attained (i.e., $80 \mathrm{~F} / \mathrm{m}$ apparent permittivity of water at a room temperature of $20^{\circ}$ ). The miniature pore pressure transducers, body pore pressure transducers, and the linear variable differential transformer (LVDT) were calibrated and then installed after saturating the soil specimen. 
A total vertical pressure of $30 \mathrm{kPa}$ was applied for 48 hours to consolidate the soil specimen; the change in volume $(\Delta \mathrm{V})$ was considered negligible (i.e., $<0.5 \mathrm{~mm}^{3} /$ hour). After placing the ballast and/or geotextile, a sinusoidal load was applied through a servo-controlled actuator. The cyclic loading was applied to the specimen through a circular loading plate with a diameter of $235 \mathrm{~mm}$, within inner cell diameter of $240 \mathrm{~mm}$. This rigid loading plate could induce the uniform stress on the subgrade soil with minimal rigid wall boundary effects (Mohammadinia et al. 2019). The details of the applied loading system have been explained elsewhere by Trani \& Indraratna (2010). In this study a uniform normal stress was applied as a minimum vertical stress, while the sinusoidal vertical cyclic stress $\left(\sigma_{\min }=30\right.$ $\mathrm{kPa}$ and $\sigma_{\max }=70-100 \mathrm{kPa}$ ) simulates a maximum axle load of 35 tonnes. The frequency was varied between 1.0 and $5.0 \mathrm{~Hz}$, which corresponds to train speeds of $45-225 \mathrm{~km} / \mathrm{h}$ (Indraratna et al. 2020c; Mamou et al. 2017; Powrie et al. 2007). Wheeler et al. (2017) reported that a single train passing at approximately $40 \mathrm{~km} / \mathrm{h}(25 \mathrm{miles} / \mathrm{h})$ could pump fluid and fines upwards, so the frequency range selected for the cyclic tests realistically agree with typically known actual range of speed of trains (minimum and maximum speed of 45 and $225 \mathrm{~km} / \mathrm{h}$ respectively). The entire test program consisted of 11 laboratory tests covering three distinct experimental phases, all of which had corroborated with the ballast-subgrade interface conditions summarised in Table 2 . The repeatability and reliability of the plotted data could be ensured by the responses of 2 additional test specimens at each test condition.

Phase 1 (without geotextiles): To define the failure criteria the tests were carried out under (a) undrained conditions where an impermeable boundary was created by a geomembrane, and (b) free drainage where there was a layer of ballast directly over the subgrade specimen. A vertical stress $\left(\sigma_{d}\right)$ of $40 \mathrm{kPa}$ (i.e. $\sigma_{\min }=30 \mathrm{kPa}, \sigma_{\max }=70 \mathrm{kPa}$ ) and $\mathrm{f}=5.0 \mathrm{~Hz}$ were applied.

Phase 2 (performance of different geotextiles): The main objective of Phase 2 was to evaluate the performance of 3 different geotextiles (G1, G2, and G3) in terms of controlling the development of EPP and preventing or delaying the initiation of subgrade fluidisation. Geotextiles were installed at the interface between the ballast and subgrade specimens and the cyclic loading was applied as described in Phase 1. 
Phase 3 (influence of frequency and amplitude): The laboratory experiments under Phase 3 were

211

212 necessary to investigate the performance of geotextiles under different axle loads and speeds. In this instance the loading frequency and amplitude were applied from 1 to $5 \mathrm{~Hz}$ and $40-70 \mathrm{kPa}$, respectively. The geotextiles at the ballast subgrade interface were selected on the basis of the results under Phase 2 .

\section{RESULTS AND DISCUSSIONS}

Phase 1: Subgrade behaviour influenced by drainage conditions at the ballast and subgrade interface

The variations of EPPs and axial strains for Tests T1 and T2 are shown in Figure 3(a) and 3(b). Test T1 is where there is no drainage at the ballast-subgrade interface (undrained), whereas Test T2 simulates the most common situation where ballast is placed directly over the subgrade soil (no capping). Test T1 shows a rapid development of EPP up to 500 cycles, after which all the miniature pressure transducer readings are above $22 \mathrm{kPa}\left(\mathrm{EPP}_{\mathrm{T} 1}\right)$, and without any significant reduction afterwards, as shown in Figure 3(a). The EPPs at depths of 40 and $80 \mathrm{~mm}$ are higher than the EPP near the top of subgrade soil. The transducer MP3 (@80 mm) has a maximum EPP of $27 \mathrm{kPa}$ after 50,000 cycles. The generation of EPP deeper in the subgrade soil profile (@40-120 mm) without continual reduction over time can lead to adverse hydraulic conditions. When free drainage is provided in Test T2, the EPPs reached a maximum at $20 \mathrm{kPa}$ after 500 cycles and decreased to $10-15 \mathrm{kPa}$ at the end of the test. In terms of deformation, the maximum axial strain for $\mathrm{T} 1$ and $\mathrm{T} 2$ after 50,000 cycles is approximately $2 \%$ and $9 \%$, respectively (Figure 3(b)), with the time-dependent axial strain for T2 always higher than that of T1. Since confinement near the interface is minimum the subgrade particles can migrate upwards and ballast particles can penetrate the subgrade layer and induce fouling. Although the EPP at 40, 80, and $120 \mathrm{~mm}$ from the interface in Test $\mathrm{T} 2$ is less than in Test 1 (undrained conditions), there is no continual reduction, even after 40,000 cycles, as shown in Figure 3(a). This shows that the selected subgrade soil has a potential for subgrade fluidisation when the axial strain exceeds $6 \%$ and the EPP does not dissipate 
continually as the loading cycles extend $\left(\mathrm{EPP}>\mathrm{EPP}_{\mathrm{T} 1}\right)$. The tests under undrained (T1) and free

237 drainage (T2) conditions were repeated to assess the repeatability of cyclic tests in the modified dynamic filtration apparatus. Similar performances were observed for the EPP and axial strain for samples tested under the same loading conditions.

240

Figure 4(a) shows the variations of liquidity index (LI) with depth after 100,000 cycles. The LI indicates the consistency of soil in comparison to its liquid and plastic limits. When LI approaches unity, the water content in the soil approaches its liquid limit that can be used to represent the fluidised state of soil (slurry). Here, the LI in both specimens varies linearly from 1 at the top to 0.2 at the bottom. Indraratna et al. (2020c) noted a similar change in the moisture content during cyclic triaxial testing under undrained conditions. Particle migration and the interlayer creation occurred after 500 cycles in $\mathrm{T} 2$, while the top layer of soil in Test $\mathrm{T} 1$ became slurry. Visual observations after 500 cycles are shown in Figure 4(b) and 4(c). In Test T1 the soil underneath the interface becomes a slurry, this is confirmed by the LI close to unity whereas the ballast layer sinks by $30 \mathrm{~mm}$ within 500 cycles, together with a rapid increase in axial strain in Test $\mathrm{T} 2$.

A Malvern particle size analyser (Mastersizer) is used to measure the particle size distribution at the top and middle regions at the end of loading. As Figure 5 shows, a lot more fines $(<75 \mu \mathrm{m})$ have accumulated near the interface of the test specimen $\mathrm{T} 1(\approx 52 \%)$ than at the middle region $(\approx 48 \%)$, which previously had approximately $50 \%$ of fines. This proves that finer particles are transported during cyclic load and the increased water content can facilitate the formation of a slurry at the interface. The drainage conditions at the interface and in the soil mean that the excess pore pressure gradient (EPPG) can be defined as the ratio between changes in the excess pore water pressure head (dUe) and the corresponding distance between two specified locations (dL). The EPPG inside the subgrade soil may create enough hydraulic pressure to pump the fines up from the soil matrix. Figure 6 shows the EPPG and the depth of subgrade in Test T1. The excess pore pressure gradient is more than 35 after 500 cycles $\left(\mathrm{EPPG}_{\mathrm{T} 1}\right)$, and it continued to increase up to 5000 cycles and then began to drop as the number of cycles increased. In Layers (2-1) and (3-2) (i.e. middle region), the EPPG reached above 45 after 5000 cycles and thus induced the migration of fines towards the top layer. 


\section{Phase 2: Performance of different geotextiles}

The performance of geotextiles (G1, G2, and G3) in terms of the EPP, the axial strain, and the excess pore pressure gradient (EPPG) have been assessed under Phase 2. With G1, a higher EPP (>30 kPa) developed within 500 cycles, but dissipated all the EPP at the end of each test. With G1, Figure 7(a) shows that all the readings from the miniature pressure transducer are lower than $22 \mathrm{kPa}\left(\mathrm{EPP}_{\mathrm{T} 1}\right)$ after 10,000 cycles, and continuously dissipated the EPP below $10 \mathrm{kPa}$ at 100,000 cycles. Unlike the other geotextiles (G2 and G3), at the end of 100,000 cycles G1 dissipated the EPP by more than $85 \%$ and $60 \%$, at 20 and $40 \mathrm{~mm}$ below the interface, respectively. Over 65,000 cycles, the readings from the MP $240 \mathrm{~mm}$ below the interface are greater than $22 \mathrm{kPa}\left(\mathrm{EPP}_{\mathrm{T} 1}\right)$ for $\mathrm{G} 2$ (Figure 7(a)) and G3 (Figure 7(b)) with relatively very low rate of dissipation compared to G1, especially near the geotextile/subgrade interface and the middle region.

The development of axial strain is controlled as the G1 prevents the formation of an interlayer creation through an additional confinement at the interface, as shown in Figure 7(c). Although the axial strain initially increased rapidly, it remained constant (around 1\%) for G1 as the number of cycles increased. While this is insignificant compared to the axial strain measured under free drainage (Test T2), there was still a continual increase in axial deformation in G2 and G3 because of the dissipation of pore pressure and particle migration through the pore openings. The residual axial strain after 100,000 cycles remains above $2 \%$ for G2 and G3. As Figure 8 shows, the EPPG that developed in G1 is $90 \%$ and $80 \%$ lower than G3 after 1000 and 100,000 cycles, respectively. This non-uniform development of EPPG (up to 75) in middle/deeper subgrade soil (the critical layers), i.e. Layers (2-1) and (3-2), creates a strong upward hydrodynamic force that dislocates the finer particles towards the top layers. The accumulation of finer particles at the ballast and geotextile interface (slurry) with the inclusion of G2 and G3, and particle migration through their pore openings could not be prevented. In fact, the percentage of fines trapped in the pore openings are 5.92, 8.12 and $9.16 \mathrm{~g}$ using G1, G2, and G3 respectively, and where the geotextile area is $4.15 \times 10^{-5} \mathrm{~m}^{2}$. The amount of fines trapped in G1 after 100,000 cycles is minimal and 35\% less than G3, which show how effectively it can prevent fines from migrating into the ballast. 
The fines that accumulated on top of the geotextiles (G1, G2 and G3) after applying the cyclic loading

292

293 are shown in Figure 9.

The efficiency at which different geotextiles could curtail the water content of subgrade soil by providing adequate drainage is shown in Figure 9(a). The water content for Tests T1 and T2 are close to the liquid limit at the interface and thus increase the potential for fluidisation as finer particles accumulate below 500 cycles. However, geotextiles helped reduce the water content of the soil, unlike the undrained (T1) and free drainage (T2) tests. The water content of the interface soil was more than $30 \%$ closer to the interface when G2 and G3 were tested under cyclic loading. The inclusion of G1 could reduce the water content by another 5\%, unlike G2 and G3. This proves that geotextile inclusion with an effective filter (G1) can prevent excessive particle migration and provide adequate drainage by dissipating the excess pore water pressure (EPP) that develops at the ballast/subballast layer. Chawla \& Shahu (2016) noted similar observations in terms of subgrade displacement and particle migration during cyclic testing under large-scale testing on full panel railway track models. In fact, the rapid generation of EPP for the next train loading can also be reduced due to the inclusion of G1 rather than G2 and G3.

\section{Phase 3: Effects of cyclic stress and frequency}

The geotextile G1 was selected for this Phase because it successfully mitigated particle migration and reduced the development of EPP in Phase 2.

\section{Effects of cyclic deviatoric stress}

As expected, a rapid development in the EPP occurred as the amplitude of cyclic stress increased, as shown in Figure 10(a). Different deviatoric stresses $\left(\sigma_{\max }\right.$ of 70,85 and $\left.100 \mathrm{kPa}\right)$ were used to demonstrate how an increased axle load (25-35 tonnes) could affect the cyclic behaviour of subgrade soil and the performance of G1. The G1 could not reduce the cyclic EPP effectively at the middle to 
lower region, i.e., at 40,80 , and $120 \mathrm{~mm}$ from the interface when $\sigma_{\max }$ increases to $100 \mathrm{kPa}$, whereas the EPPs remained above $40 \mathrm{kPa}$ within 500 cycles until the test ended. Figure 10(a) shows an approximately 85\% lower in EPP $120 \mathrm{~mm}$ below the interface in Test D70 compared to Test D100 after 80,000 cycles. The increasing trend in axial strain in D100 attains 5\% before 75,000 cycles (Figure 10(b)), which may induce instability due to excessive deformation. Figure 11 shows that the maximum EPPG of 225 in Layer (3-2) occurred in less than 1000 cycles during Test D100. However, in Test D70 the EPPGs of the top layers (i.e., Layers (2-1), (3-2) and (4-3)) dropped to 10 after 1000 cycles and remained constant. In test D100, the rate of dissipation in EPPG in the critical layers of soil is minimal compared to D70 after 1000 cycles, as a result that could create enough hydraulic pressure to dislocate the fines.

There was no continual particle migration through the geotextile in Tests D70 and D85, but the severe clogging and pumped-up fines observed at the interface in Test D100 due to cyclic loading is shown in Figure 12(b), 12(c) and 12(d). When compared to the results under lower cyclic stresses (D70 and D85), there was an approximately $5 \%$ increase in the water content at the interface (Test D100), as shown in Figure 12(a). This proves that G1 could not prevent the rapid increase in EPP and axial strain as the cyclic stress increased, i.e., $\sigma_{\max }$ of $100 \mathrm{kPa}$ (approximately 35 tonnes of axle loading). Accumulated fines may therefore clog the pore openings of geotextiles and hinder the performance of geotextile in terms of filtration and drainage.

\section{Effect of Frequency}

Figure 13 shows the evolution in excess pore pressure (EPP) and axial strain that corresponds to the cyclic load applied at different frequencies. Two different frequencies, i.e., 3 and $5 \mathrm{~Hz}$ were used to compare and highlight the effect of frequency on the behaviour of soil. As shown in Figure 13(a), the larger frequency $(\mathrm{f}=5 \mathrm{~Hz}$ ) leads to a $54 \%$ reduction in the EPP $120 \mathrm{~mm}$ below the interface after 50,000 cycles, unlike the smaller frequency ( $f=3 \mathrm{~Hz}$ ). Moreover, the residual EPP for $\mathrm{f}=3 \mathrm{~Hz}$ is more than $22 \mathrm{kPa}\left(\mathrm{EPP}_{\mathrm{T} 1}\right)$ after 50,000 cycles, and finer particles are easier to pump up and are more vulnerable to fluidisation under a lower frequency. This result corresponds to a greater accumulation of residual axial strain ( $2.5 \%$ at 50,000 cycles) under a lower frequency ( $\mathrm{f}=3 \mathrm{~Hz})$ as shown in Figure 13(b), and 
similar observations for soil specimens under cyclic loading have been reported by Indraratna et al. (2020b). The EPPG plotted in Figure 13(c) shows the huge development in EPPG observed after 500 cycles in the deeper soil (i.e., Layer (3-2) and Layer (4-3)). In test F3, the EPPG is above 55 and 30 in Layer (4-3) and Layer (3-2) after 10,000 cycles, and there is no significant reduction until it reached 50,000 cycles. Due to the increased EPPG, the void ratio of the soil layers changed due to pumped-up fines from the middle to the lower region of subgrade soil and towards the top. When compared to the results under lower frequencies (F1 and F3), there was an approximately 3\% reduction in the water content at the interface for Test F5, as shown in Figure 14(a). Severe clogging and migrated fine particles observed at the interface in Tests F1 and F3 compared to F5, due to cyclic loading as shown in Figure 14. This smaller frequency implies a longer period for the load to make contact with the soil before unloading in each cycle, which led to a larger residual excess pore pressure (EPP) and axial strain in the test specimens. These observations support that train loading with a smaller frequency can initiate an earlier fluidisation under the same loading conditions.

\section{CONCLUSION}

The dynamic filtration tests were carried out to investigate the subgrade-subballast interface with enhanced drainage conditions due to the use of geosynthetics. In this study, (1) undrained, (2) partially drained, and (3) free drainage conditions were used to characterise subgrade fluidisation under heavy haul train loading. This study explained and discussed the role of geosynthetics as a drainage medium and filter in railway tracks to prevent particle migration and associated subgrade fluidisation. This study found that the threshold cyclic stress, the loading frequency, and the inclusion of geosynthetics could contribute to subgrade fluidisation as local excess pore pressures, excess pore pressure gradients, and upward fine and moisture migration evolves.

The major findings based on this study are as follows: 
abrupt change in the water content along the height of the specimen and a finer fraction of less than $75 \mu \mathrm{m}$ pumped up from underneath soil became slurry at the top, whereas Test T2 (Free drainage) showed excessive deformation $\left(\varepsilon_{\mathrm{a}}>6 \%\right.$ at 500 cycles $)$ and fouling at the ballast and subgrade interface without surface confinement. This concludes that subgrade soil subjected to repetitive cyclic loading generates higher EPP without continual dissipation can result in

- The inclusion of geotextile (G1) could dissipate the EPP, reduce overall deformation, and particle separation and associates subgrade fluidization under adverse hydraulic conditions in railway tracks. prevent fine particles from migrating under cyclic loading conditions better than in Tests T1 and T2. For example, G1 maintained the EPP at less than $10 \mathrm{kPa}$, which is approximately $55 \%$ of the EPP developed in Test T1 at 100,000 cycles, while the axial strain was less than $1 \%$ for the same loading conditions ( $\sigma_{\max }=70 \mathrm{kPa}$ ). The EPP developed for G2 and G3 were higher than $\mathrm{EPP}_{\mathrm{T} 1}$ after 10,000 cycles, and the rate of dissipation was not significant until the test ended. The aperture opening size of the filter (G1) is less than $1 \mu \mathrm{m}$, as reported in Table 1 , but it can still prevent particle migration and dissipate the EPP under cyclic loading. The larger pore openings in G2 and G3 could not prevent the particle migration and then became more clogged with fines than G1. This proves that the G1 effectively reduces the accumulation of EPP with time and prevents particle migration through the interface.

- The EPPG generated by cyclic excess pore water pressure plays a crucial role in inducing fines to migrate from the middle region towards the top of the sample. For instance, in Test T1 the EPPG that developed approximately $100 \mathrm{~mm}$ from the interface was more than 35 only after 500 cycles i.e., with less than 2 minutes of train loading. However, the installation of G1 reduced the EPPG by $90 \%$ after 1000 cycles in the middle layer, and it remained below 10 until the test ended. This significant reduction in EPPG reduced the migration of fines by more than 35\% than the other geotextiles (G2 and G3). These results imply that the geotextile (G1) with an enhanced drainage capacity can reduce EPPG developed inside the subgrade soil, and thus prevents the finer particle separation from the soil matrix. 
- Soil under lower frequencies may become more prone to subgrade fluidisation. The soil specimen subjected to $\mathrm{f}=5 \mathrm{~Hz}$ experienced around $50 \%$ reduction in the EPP in the middle region after 50,000 cycles, compared to the specimen under $\mathrm{f}=3 \mathrm{~Hz}$. The increase in cyclic stress also led to the development of axial strain and EPP with the inclusion of G1 when the cyclic deviator stress was more than $70 \mathrm{kPa}$. Specifically, in Tests D70 and D85, the readings from the miniature pore pressure transducers near the interface within $40 \mathrm{~mm}$ below the interface were below $\mathrm{EPP}_{\mathrm{T} 1}$ and the EPPs that developed for Test D100 were $300 \%$ to $400 \%$ higher than Test D70 at 100,000 cycles. The EPPG was above $35\left(\mathrm{EPPG}_{\mathrm{T} 1}\right)$ in the middle layers of soil up to 40,000 cycles and reached 5\% of axial strain before 75,000 cycles (Tests D100). The laboratory experiments show that the fine particle migration was significant with increased cyclic stress. At the ballast subgrade interface, contact pressure due to the train loading and CSR is maximum at the location directly beneath the rails and it decreases towards the centreline and the ballast shoulders. These results imply that the potential for fine migration can become less as CSR decreases, and subsequent fluidisation can be triggered at lower frequencies in tracks under poor drainage conditions.

- The results of this study clearly suggest that selected geotextile G1 can prevent particle migration and dissipate the EPP at lower axle loads (25-30 tonne axle load). However, during the passage of heavy haul trains with an axle load up to 40 tonnes ( $\sigma_{\max }$ of $\left.140 \mathrm{kPa}\right)$, the ability of G1 to prevent subgrade fluidisation and associated mud pumping can diminish.

\section{ACKNOWLEDGEMENT}

This research was supported by the Australian Research Council's Industrial Transformation Training Centre for Advanced Technologies in Rail Track Infrastructure (ITTC-Rail). The material support from Polyfabrics Australasia is acknowledged. The series of laboratory experiments was conducted while the first author was a $\mathrm{PhD}$ student at the University of Wollongong. 


\section{REFERENCES}

Alobaidi, I. \& Hoare, D. 1994, 'Factors affecting the pumping of fines at the subgrade subbase interface of highway pavements: a laboratory study', Geosynthetics International, vol. 1, no. 2, pp. 22159.

Alobaidi, I. \& Hoare, D. 1998, 'The role of geotextile reinforcement in the control of pumping at the subgrade-subbase interface of highway pavements', Geosynthetics International, vol. 5, no. 6, pp. 619-36.

Alobaidi, I. \& Hoare, D. 1999, 'Mechanisms of pumping at the subgrade-subbase interface of highway pavements', Geosynthetics International, vol. 6, no. 4, pp. 241-59.

Alobaidi, I. \& Hoare, D.J. 1996, 'The development of pore water pressure at the subgrade-subbase interface of a highway pavement and its effect on pumping of fines', Geotextiles and geomembranes, vol. 14, no. 2, pp. 111-35.

Arulrajah, A., Abdullah, A., Bo, M.W. \& Bouazza, A. 2009, 'Ground improvement techniques for railway embankments', Proceedings of the Institution of Civil Engineers-Ground Improvement, vol. 162 , no. 1 , pp. $3-14$.

Arulrajah, A., Abdullah, A., Bo, M.W. \& Leong, M. 2015, 'Geosynthetic applications in high-speed railways: a case study', Proceedings of the institution of civil engineers-ground improvement, vol. 168 , no. 1 , pp. 3-13.

ASTM D5856-95 2002, Standard test method for measurement of hydraulic conductivity of porous material using a rigid-wall, compaction-mold permeameter, West Conshohocken, PA, USA: American Society for Testing and Materials.

ASTM D422-63 2007, Standard Test Method for Particle-Size Analysis of Soils, ASTM International West Conshohocken, PA.

ASTM D698-00 2000, Standard Test Methods for Laboratory Compaction Characteristics of Soil Using Standard Effort (12,400 ft-lbf/ft3 (600 kN-m/m3)), Annual Book of ASTM Standards.

ASTM D854-02 2002, Standard test method for specific gravity of soil solids by water pycnometer, American Society for Testing and Materials West Conshohocken, PA. 
ASTM D3999-91 2003, Standard Test Methods for the Determination of the Modulus and Damping Properties of Soils using the Cyclic Triaxial Apparatus, Annual Book of ASTM standards.

ASTM D4318-00 2003, Standard Test Methods for Liquid Limit, Plastic Limit, and Plasticity Index of Soils, Annual Book of ASTM Standards, American Society For Testing and Materials, West Conshohocken, PA.

ASTM D4491-99 1999, Standard test method from water permeability of Geotextiles by permitivity, American Society for Testing Materials.

ASTM F316-03 2011, Standard Test Methods for Pore Size Characteristics of Membrane Filters by Bubble Point and Mean Flow Pore Test, ASTM International, West Conshohocken, PA, 2003.

Aw, E.S. 2007, 'Low cost monitoring system to diagnose problematic rail bed: case study of mud pumping site', Massachusetts Institute of Technology.

Aydilek, A.H., Oguz, S.H. \& Edil, T.B. 2002, 'Digital image analysis to determine pore opening size distribution of nonwoven geotextiles', Journal of Computing in Civil Engineering, vol. 16, no. 4, pp. 280-90.

Ayres, D. 1986, 'Geotextiles or geomembranes in track? British railways' experience', Geotextiles and Geomembranes, vol. 3, no. 2-3, pp. 129-42.

Bhatia, S. \& Smith, J. 1996, 'Geotextile characterization and pore-size distribution: Part II. A review of test methods and results', Geosynthetics International, vol. 3, no. 2, pp. 155-80.

Bhatia, S.K. \& Huang, Q. 1995, 'Geotextile filters for internally stable/unstable soils', Geosynthetics International, vol. 2, no. 3, pp. 537-65.

Boomintahan, S. \& Srinivasan, G. 1988, 'Laboratory studies on mud-pumping into ballast under repetitive rail loading', Indian geotechnical journal, vol. 18, no. 1, pp. 31-47.

Chawla, S. \& Shahu, J. 2016, 'Reinforcement and mud-pumping benefits of geosynthetics in railway tracks: Model tests', Geotextiles and Geomembranes, vol. 44, no. 3, pp. 366-80.

Duong, T.V., Cui, Y.-J., Tang, A.M., Dupla, J.-C., Canou, J., Calon, N. \& Robinet, A. 2014, 'Investigating the mud pumping and interlayer creation phenomena in railway sub-structure', Engineering Geology, vol. 171, pp. 45-58. 
EN ISO 9863-1 2005, Geosynthetics-Determination of thickness at specified pressures. Part 1: Single Layers, CEN, Brusel.

EN ISO 10319 2008, Geosynthetics-Wide-width tensile test., International Organization for Standardization, Geneva, Switzerland.

EN ISO 12236 2006, Geosynthetics-Static Puncture Test (CBR Test), European Committee for Standardization, Brussels, Belgium.

Faure, Y.-H., Baudoin, A., Pierson, P. \& Ple, O. 2006, 'A contribution for predicting geotextile clogging during filtration of suspended solids', Geotextiles and Geomembranes, vol. 24, no. 1, pp. 1120.

Feng, W.-Q., Li, C., Yin, J.-H., Chen, J. \& Liu, K. 2019, 'Physical model study on the clay-sand interface without and with geotextile separator', Acta Geotechnica, vol. 14, no. 6, pp. 2065-81.

Fiberweb 2012, Product data sheets. Fiberweb Geosynthetics Ltd, Blackwater Industrial Estate, The Causeway, Maldon, CM9 4GG.

Ghataora, G., Burns, B., Burrow, M. \& Evdorides, H. 2006, 'Development of an index test for assessing anti-pumping materials in railway track foundations', Proceedings of the First International Conference on Railway Foundations, Railfound06, University of Birmingham, UK, pp. 35566.

Ghosh, C. \& Yasuhara, K. 2004, 'Clogging and flow characteristics of a geosynthetic drain confined in soils undergoing consolidation', Geosynthetics International, vol. 11, no. 1, pp. 19-34.

Hayashi, S. \& Shahu, J. 2000, 'Mud pumping problem in tunnels on erosive soil deposits', Geotechnique, vol. 50, no. 4, pp. 393-408.

Hudson, A., Watson, G., Le Pen, L. \& Powrie, W. 2016, 'Remediation of mud pumping on a ballasted railway track', Procedia engineering, vol. 143, pp. 1043-50.

Indraratna, B., Ionescu, D. \& Christie, H. 1998, 'Shear behavior of railway ballast based on large-scale triaxial tests', Journal of geotechnical and geoenvironmental Engineering, vol. 124, no. 5, pp. 439-49.

Indraratna, B., Korkitsuntornsan, W. \& Nguyen, T.T. 2020a, 'Influence of Kaolin content on the cyclic loading response of railway subgrade', Transportation Geotechnics, vol. 22, p. 100319. 
Indraratna, B., Phan, N.M., Nguyen, T.T. \& Huang, J. 2021, 'Simulating Subgrade Soil Fluidization Using LBM-DEM Coupling', International Journal of Geomechanics, vol. 21, no. 5, p. 04021039.

Indraratna, B., Singh, M. \& Nguyen, T.T. 2020b, 'The mechanism and effects of subgrade fluidisation under ballasted railway tracks', Railway Engineering Science, vol. 28, pp. 113-28.

Indraratna, B., Singh, M., Nguyen, T.T., Leroueil, S., Abeywickrama, A., Kelly, R. \& Neville, T. 2020c, 'Laboratory study on subgrade fluidization under undrained cyclic triaxial loading', Canadian Geotechnical Journal, vol. 57, no. 11, pp. 1767-79.

Israr, J. \& Indraratna, B. 2017, 'Internal stability of granular filters under static and cyclic loading', Journal of Geotechnical and Geoenvironmental Engineering, vol. 143, no. 6, p. 04017012.

Israr, J., Indraratna, B. \& Rujikiatkamjorn, C. 2016, 'Laboratory investigation of the seepage induced response of granular soils under static and cyclic loading', Geotechnical Testing Journal, vol. 39, no. 5, pp. 795-812.

Jiang, M., Konrad, J. \& Leroueil, S. 2003, 'An efficient technique for generating homogeneous specimens for DEM studies', Computers and geotechnics, vol. 30, no. 7, pp. 579-97.

Kamruzzaman, A., Haque, A. \& Bouazza, A. 2008, 'Filtration behaviour of granular soils under cyclic load', Geotechnique, vol. 58, no. 6, pp. 517-22.

Kermani, B., Stoffels, S. \& Xiao, M. 2020, 'Evaluation of effectiveness of geotextile in reducing subgrade migration in rigid pavement', Geosynthetics International, vol. 27, no. 1, pp. 97-109.

Kermani, B., Xiao, M., Stoffels, S.M. \& Qiu, T. 2018, 'Reduction of subgrade fines migration into subbase of flexible pavement using geotextile', Geotextiles and Geomembranes, vol. 46, no. 4, pp. 377-83.

Khan, M., Dawson, A. \& Marshall, A. 2018, 'A dynamic gradient ratio test apparatus', Geotextiles and Geomembranes, vol. 46, no. 6, pp. 782-9.

Kuo, C., Hsu, C., Wu, C., Liu, P. \& Chen, D. 2017, 'Study on the Piping Path and Mechanism of Mudpumping in Railway Subgrade', The 19th international conference on soil mechanics and geotechnical engineering, Seoul, South Korea. 
Liu, D., Fu, H.L., Zhu, X.Z., Liu, Y.S. \& Rao, J.Y. 2013, 'Study on the Remediation of Mud-Pumping', vol. 275, Trans Tech Publ, pp. 1560-3.

Liu, S., Huang, H., Qiu, T. \& Kerchof, B. 2019, 'Characterization of ballast particle movement at mud spot', Journal of Materials in Civil Engineering, vol. 31, no. 1, p. 04018339.

Luettich, S., Giroud, J. \& Bachus, R. 1992, 'Geotextile filter design guide', Geotextiles and Geomembranes, vol. 11, no. 4-6, pp. 355-70.

Mamou, A., Powrie, W., Priest, J. \& Clayton, C. 2017, 'The effects of drainage on the behaviour of railway track foundation materials during cyclic loading', Géotechnique, vol. 67, no. 10, pp. 845-54.

Moffat, R. \& Herrera, P. 2015, 'Hydromechanical model for internal erosion and its relationship with the stress transmitted by the finer soil fraction', Acta Geotechnica, vol. 10, no. 5, pp. 643-50.

Mohammadinia, A., Arulrajah, A., Disfani, M.M. \& Darmawan, S. 2019, 'Small-Strain Behavior of Cement-Stabilized Recycled Concrete Aggregate in Pavement Base Layers', Journal of Materials in Civil Engineering, vol. 31, no. 5.

Muramoto, K., Sekine, E. \& Nakamura, T. 2006, 'Roadbed degradation mechanism under ballastless track and its countermeasures', Quarterly Report of RTRI, vol. 47, no. 4, pp. 222-7.

Nguyen, T.T. \& Indraratna, B. 2021, 'Rail track degradation under mud pumping evaluated through site and laboratory investigations', International Journal of Rail Transportation, pp. 1-28.

Nguyen, T.T., Indraratna, B., Kelly, R., Phan, N.M. \& Haryono, F. 2019, 'Mud pumping under railtracks: mechanisms, assessments and solutions', Aust Geomech J, vol. 54, no. 4, pp. 59-80.

Palmeira, E., Fannin, R. \& Vaid, Y. 1997, 'A study on the behaviour of soil geotextile systems in filtration tests', Canadian Geotechnical Journal, vol. 33, no. 6, pp. 899-912.

Palmeira, E. \& Gardoni, M. 2000, 'The influence of partial clogging and pressure on the behaviour of geotextiles in drainage systems', Geosynthetics International, vol. 7, no. 4-6, pp. 403-31.

Palmeira, E.M. 2009, 'Soil-geosynthetic interaction: Modelling and analysis', Geotextiles and geomembranes, vol. 27, no. 5, pp. 368-90.

Palmeira, E.M., Melo, D.L. \& Moraes-Filho, I.P. 2019, 'Geotextile filtration opening size under tension and confinement', Geotextiles and Geomembranes, vol. 47, no. 4, pp. 566-76. 
Powrie, W., Yang, L. \& Clayton, C.R. 2007, 'Stress changes in the ground below ballasted railway track during train passage', Proceedings of the Institution of Mechanical Engineers, Part F: Journal of Rail and Rapid Transit, vol. 221, no. 2, pp. 247-62.

Rajagopal, K. 2017, 'The Geosynthetics for Sustainable Construction of Infrastructure Projects', Indian Geotechnical Journal, vol. 47, no. 1, pp. 2-34.

Rajagopal, K., Chandramouli, S., Parayil, A. \& Iniyan, K. 2014, 'Studies on geosynthetic-reinforced road pavement structures', International Journal of Geotechnical Engineering, vol. 8, no. 3, pp. 287-98.

Raymond, G.P. 1986, 'Geotextile Application for a branch line upgrading', Geotextiles and Geomembranes, vol. 3, no. 2-3, pp. 91-104.

Sabiri, N.-E., Caylet, A., Montillet, A., Le Coq, L. \& Durkheim, Y. 2020, 'Performance of nonwoven geotextiles on soil drainage and filtration', European Journal of Environmental and Civil Engineering, vol. 24, no. 5, pp. 670-88.

Selig, E.T. \& Waters, J.M. 1994, Track geotechnology and substructure management, Thomas Telford.

Tennakoon, N. \& Indraratna, B. 2014, 'Behaviour of clay-fouled ballast under cyclic loading', Géotechnique, vol. 64, no. 6, pp. 502-6.

Trani, L.D.O. \& Indraratna, B. 2010, 'Use of impedance probe for estimation of porosity changes in saturated granular filters under cyclic loading: calibration and application', Journal of geotechnical and geoenvironmental engineering, vol. 136, no. 10, pp. 1469-74.

Trinh, V.N., Tang, A.M., Cui, Y.-J., Dupla, J.-C., Canou, J., Calon, N., Lambert, L., Robinet, A. \& Schoen, O. 2012, 'Mechanical characterisation of the fouled ballast in ancient railway track substructure by large-scale triaxial tests', Soils and foundations, vol. 52, no. 3, pp. 511-23.

Voottipruex, P. \& Roongthanee, J. 2003, 'Prevention of mud pumping in railway embankment a case study from Baeng Pra-pitsanuloke, Thailand', The Journal of KMITB, vol. 13, no. 1, pp. 20-5.

Wheeler, L.N., Take, W.A. \& Hoult, N.A. 2017, 'Performance assessment of peat rail subgrade before and after mass stabilization', Canadian Geotechnical Journal, vol. 54, no. 5, pp. 674-89. 
599

600

601

602

603

604

605

606

607

608

609

610

611

612

613

Williams, N.D. \& Abouzakhm, M.A. 1989, 'Evaluation of geotextile/soil filtration characteristics using the hydraulic conductivity ratio analysis', Geotextiles and Geomembranes, vol. 8, no. 1, pp. 126.

Xiao, M. \& Reddi, L.N. 2000, 'Comparison of fine particle clogging in soil and geotextile filters', Advances in Transportation and Geoenvironmental Systems Using Geosynthetics, pp. 176-85.

Yu, S., Wu-ming, L., Ji-dong, T., Ru-song, N. \& Qi, Y. 2016, 'Analysis of subgrade soil mud pumping model', Electronic Journal of Geotechnical Engineering, vol. 21, no. 24, pp. 7667-78.

Zhang, S., Gao, F., He, X., Chen, Q. \& Sheng, D. 2021, 'Experimental study of particle migration under cyclic loading: effects of load frequency and load magnitude', Acta Geotechnica, pp. 1-14.

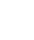

(1)

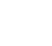


Table 1: Properties of tested geosynthetics

\begin{tabular}{|c|c|c|c|}
\hline Geosynthetics & G1 & G2 & G3 \\
\hline & & & \\
\hline $\begin{array}{c}\text { Thickness (mm) @2 kPa } \\
\text { (EN ISO 9863-1 2005) }\end{array}$ & 4.5 & 2.5 & 3.5 \\
\hline $\begin{array}{c}\text { Mean peak tensile } \\
\text { strength (kN/m) } \\
\text { (EN ISO 10319 2008) }\end{array}$ & 50 & 52.5 & 30 \\
\hline $\begin{array}{c}\text { Aperture Opening Size } \\
\text { ( } \mu \text { m) } \\
\text { (ASTM F316-03 2011) }\end{array}$ & $<1$ & 60 & 75 \\
\hline $\begin{array}{c}\text { CBR Puncture } \\
\text { Resistance (kN) - } \\
(\text { EN ISO 12236 2006) }\end{array}$ & 10 & 9 & 5 \\
\hline
\end{tabular}

618

Table 2: Experimental phases

\begin{tabular}{|c|c|c|c|c|c|}
\hline \multirow{2}{*}{ Phase } & $\begin{array}{c}\text { Test } \\
\text { No. }\end{array}$ & $\begin{array}{c}\text { Drainage condition at ballast- } \\
\text { subgrade interface }\end{array}$ & $\sigma_{\min }(\mathbf{k P a})$ & $\begin{array}{c}\sigma_{\text {max }} \\
(\mathbf{k P a})\end{array}$ & $\begin{array}{c}\text { Frequency } \\
(\mathbf{H z})\end{array}$ \\
\hline \multirow{2}{*}{1} & T1 & Undrained & 30 & 70 & 5 \\
\cline { 2 - 6 } & T2 & Free drainage (No capping) & 30 & 70 & 5 \\
\hline \multirow{3}{*}{2} & G1 & Partially drained with G1 & 30 & 70 & 5 \\
\cline { 2 - 6 } & G2 & Partially drained with G2 & 30 & 70 & 5 \\
\cline { 2 - 6 } & G3 & Partially drained with G3 & 30 & 70 & 5 \\
\hline \multirow{4}{*}{3} & D70 & Partially drained with G1 & 30 & 70 & 5 \\
\cline { 2 - 6 } & D85 & Partially drained with G1 & 30 & 85 & 5 \\
\cline { 2 - 6 } & D100 & Partially drained with G1 & 30 & 100 & 5 \\
\cline { 2 - 6 } & F1 & Partially drained with G1 & 30 & 70 & 1 \\
\cline { 2 - 6 } & F3 & Partially drained with G1 & 30 & 70 & 3 \\
\cline { 2 - 6 } & F5 & Partially drained with G1 & 30 & 70 & 5 \\
\hline
\end{tabular}



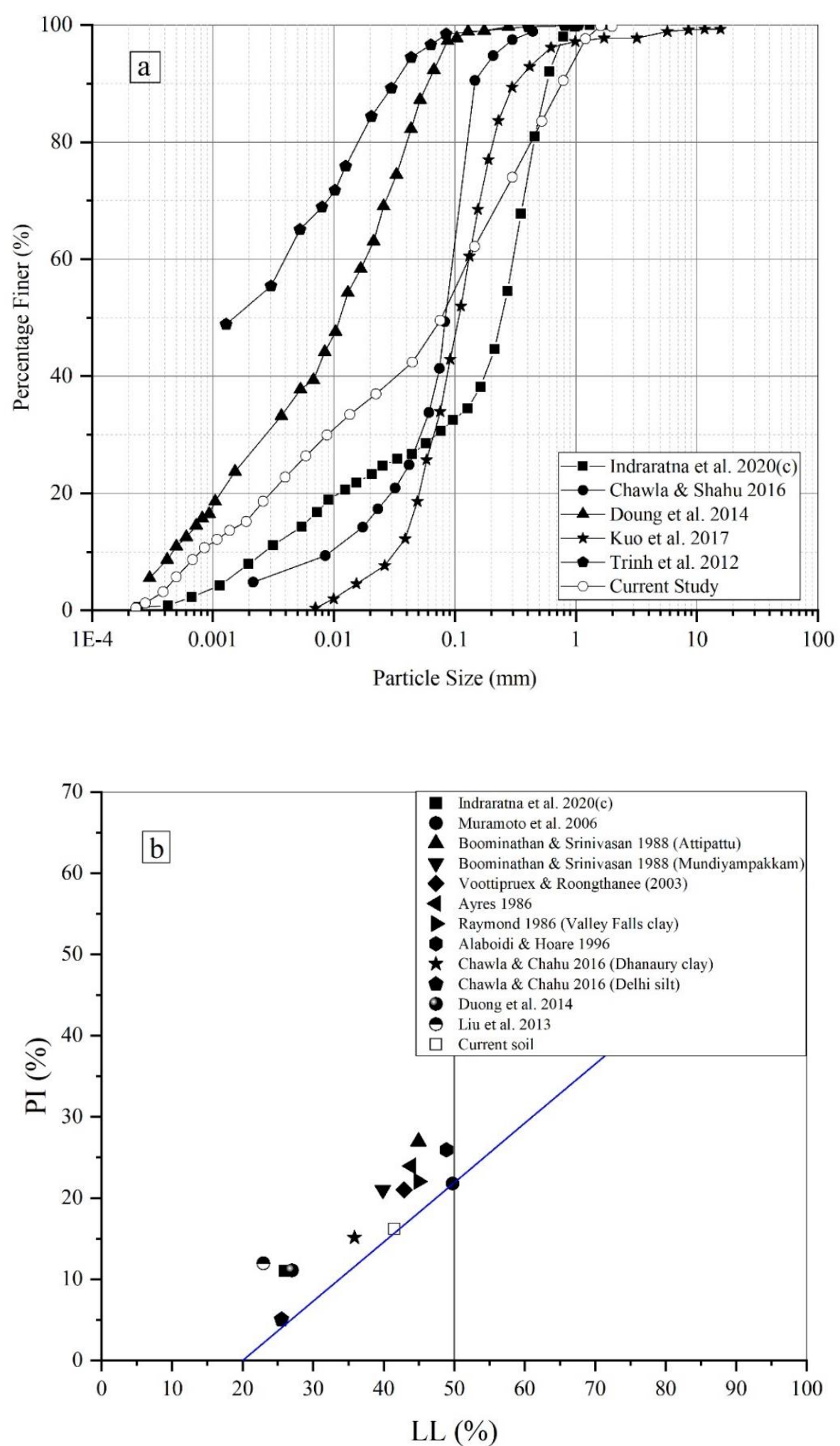

Figure 1: Soils at mud pumping sites (a) particle-size distribution and (b) Plasticity Index 

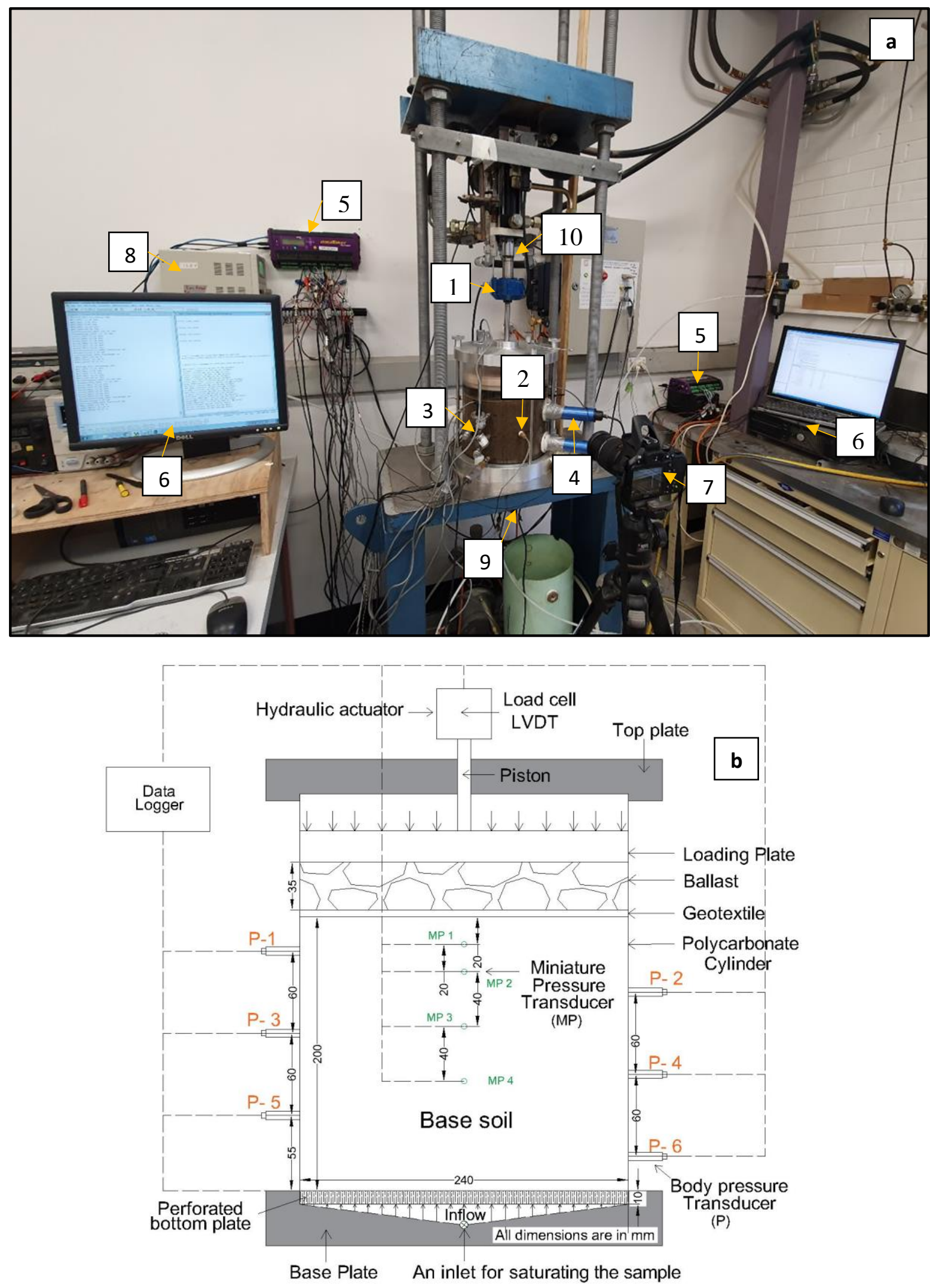

624 Figure 2: Dynamic filtration apparatus (a) Photo (b) Schematic illustration of the cell with locations of instrumentation 


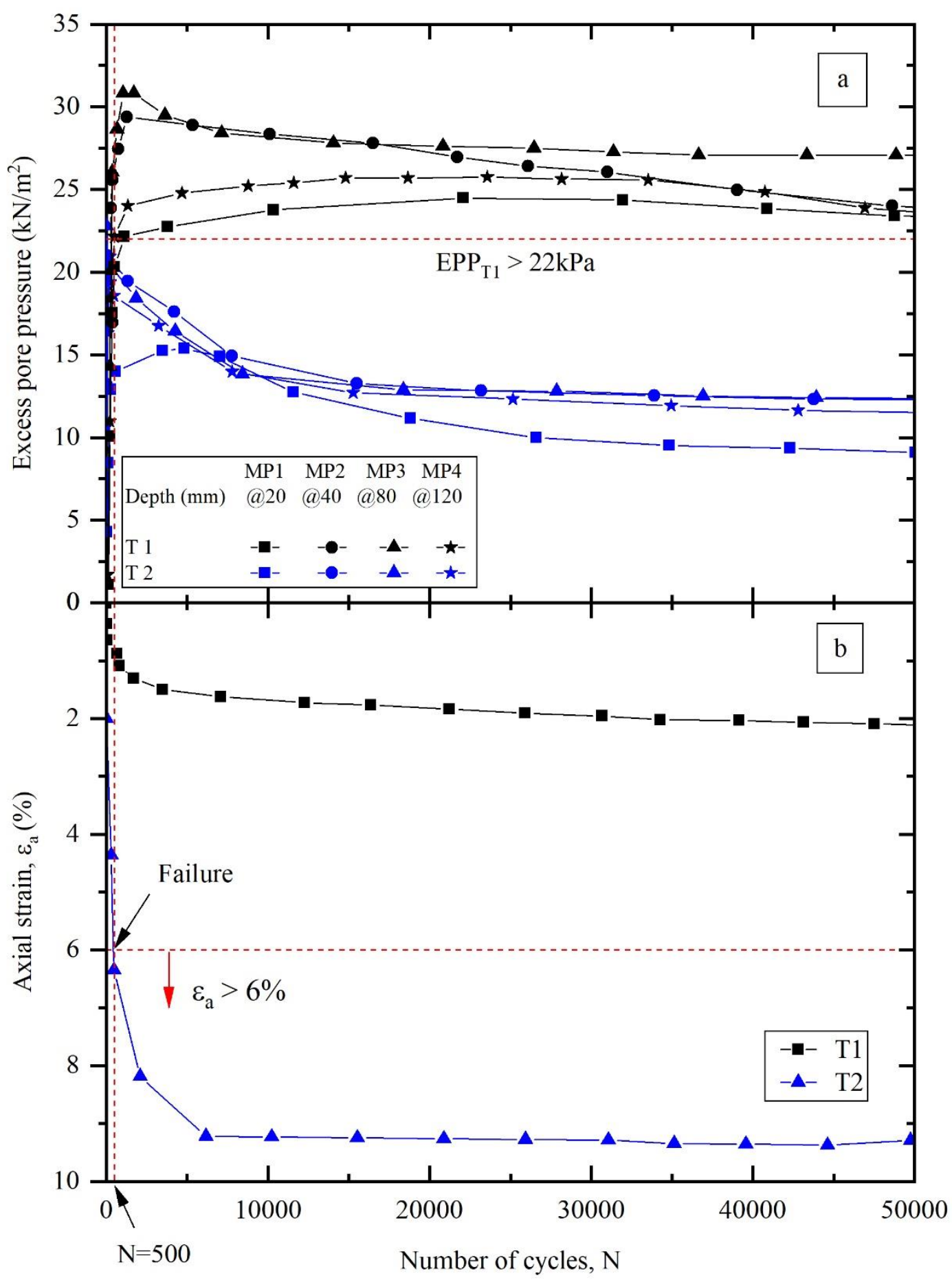

Figure 3: Tests T1 and T2 (a) Excess pore water pressure and (b) Axial strain 

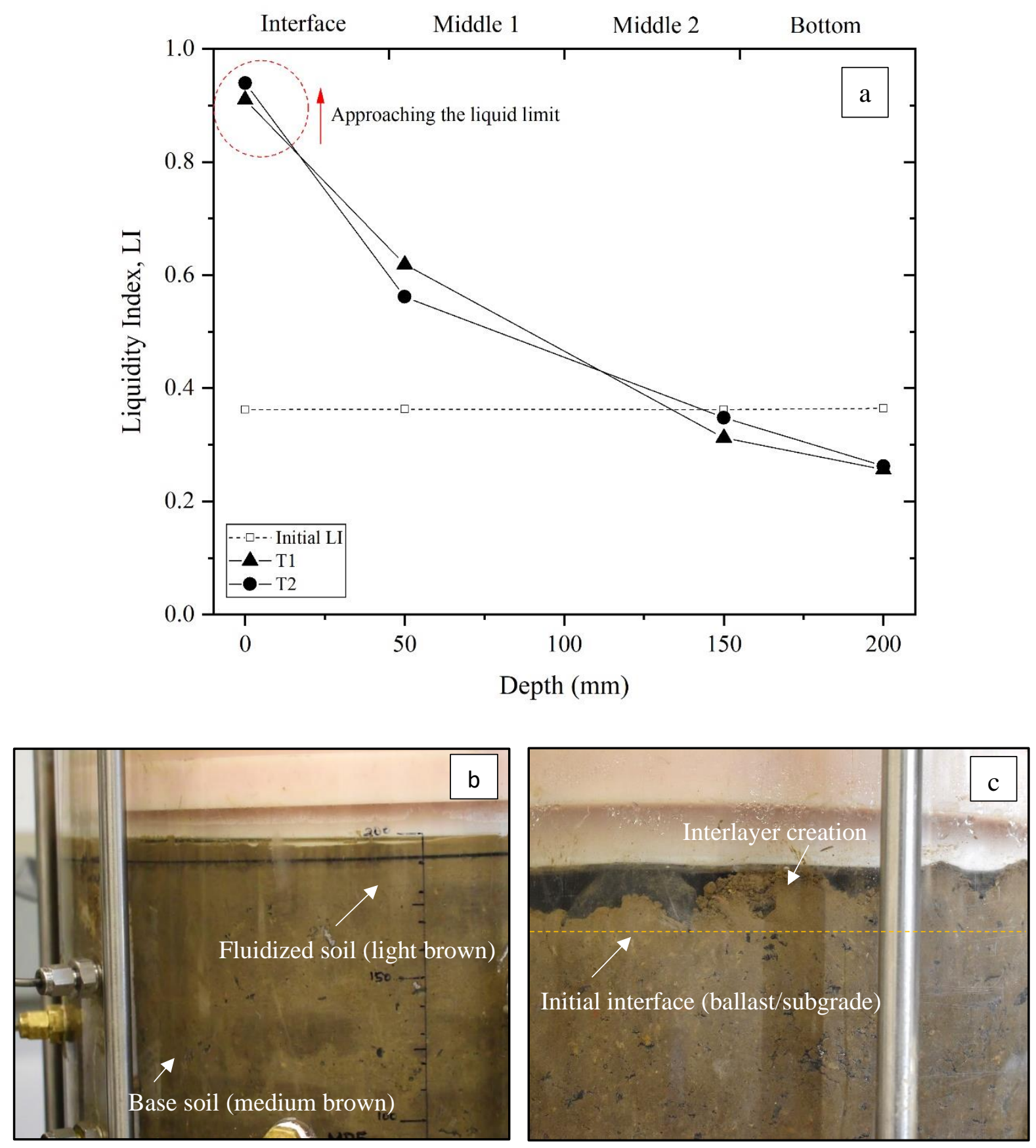

Figure 4: (a) Liquidity Index of the soil after cyclic load at various depths (b) fluidised specimen after 500 cycles for Test T1, and (c) interlayer creation due to the penetration of ballast into subgrade for 


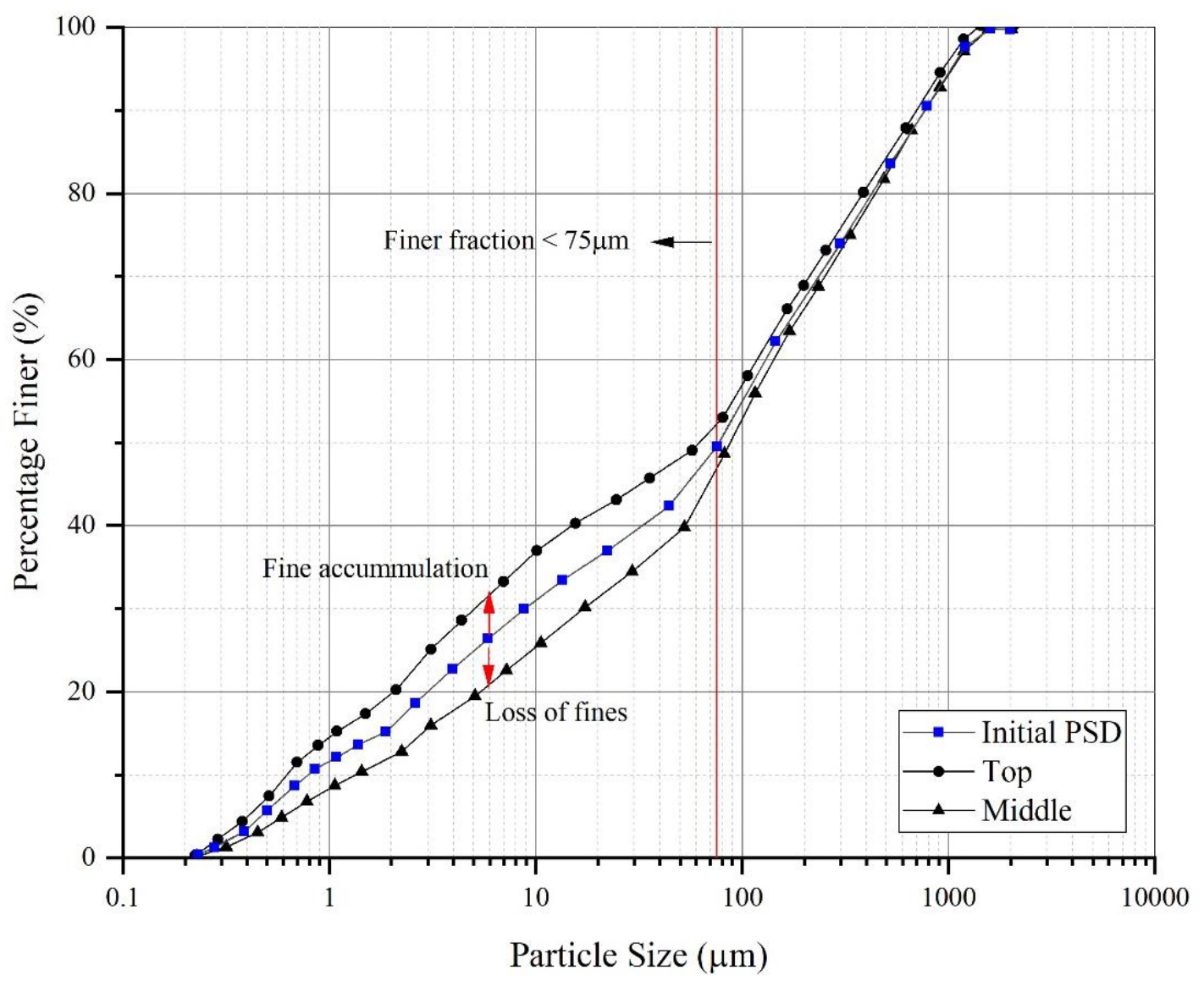

Figure 5: Particle size distributions after cyclic load for Test T1 


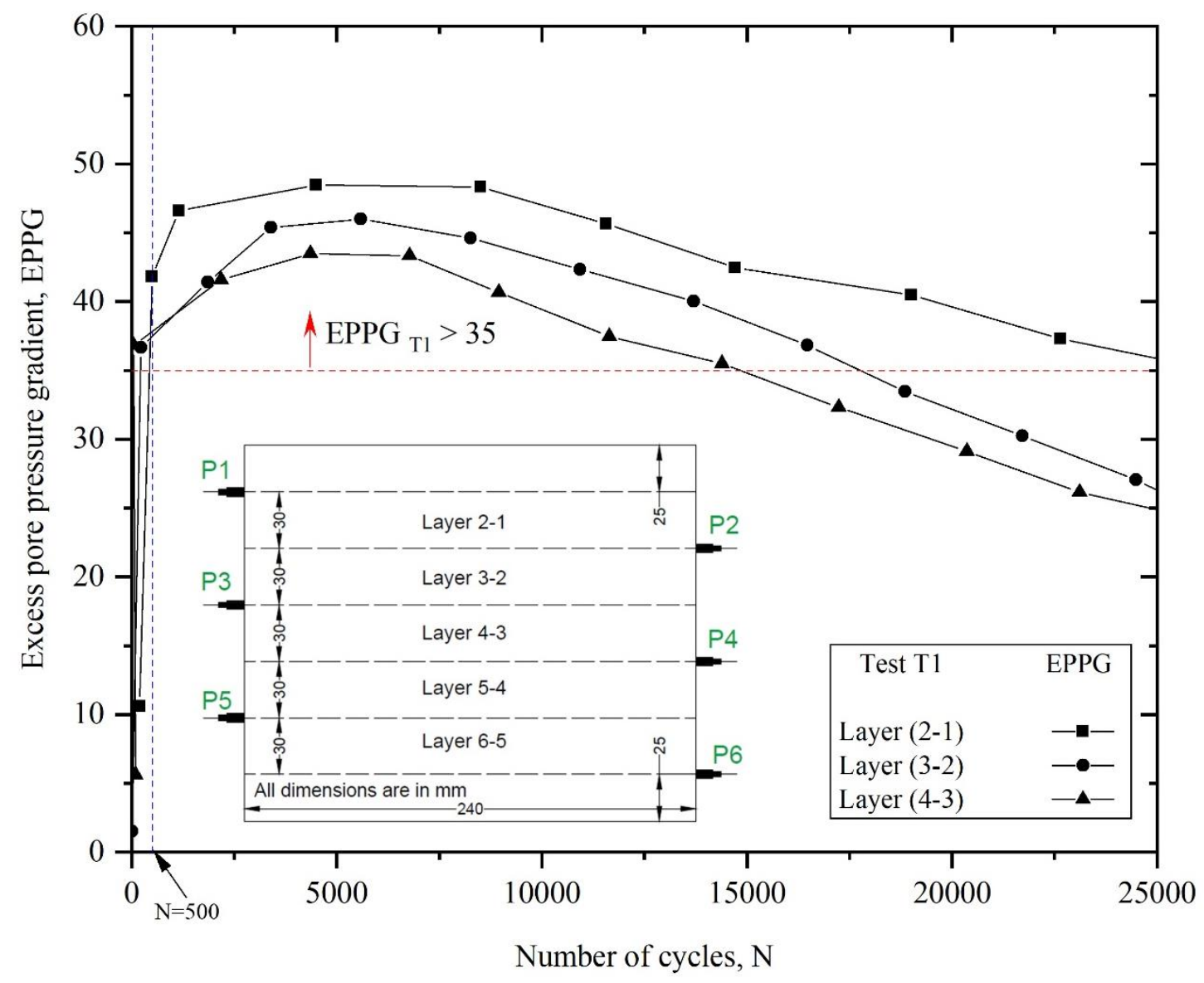

Figure 6: Excess Pore Pressure Gradients for Test T1 

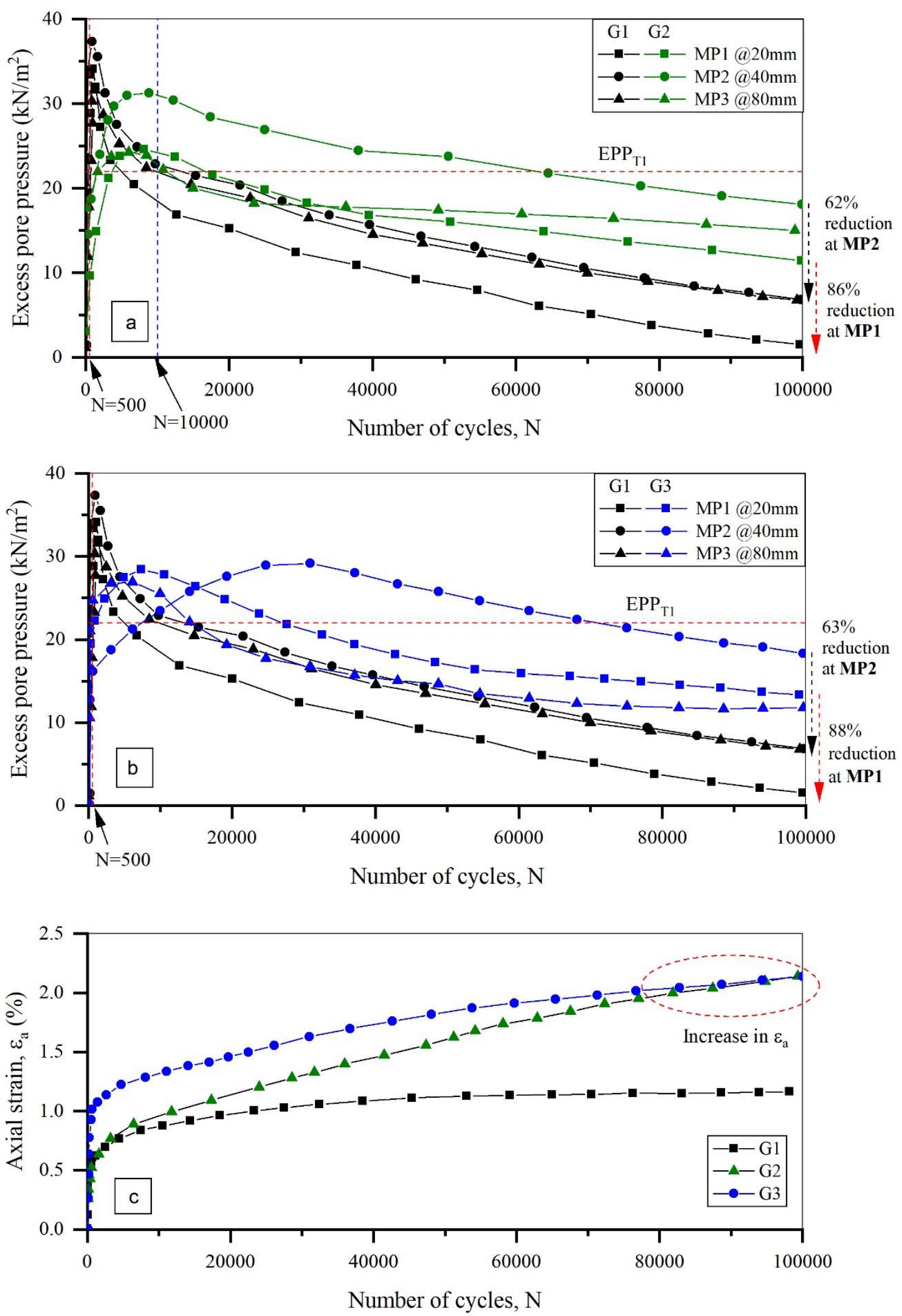

Figure 7: Excess pore water pressures (a) Tests G1 and G2 (b) Tests G1 and G3 (c) Axial strains for

Tests G1, G2, and G3 


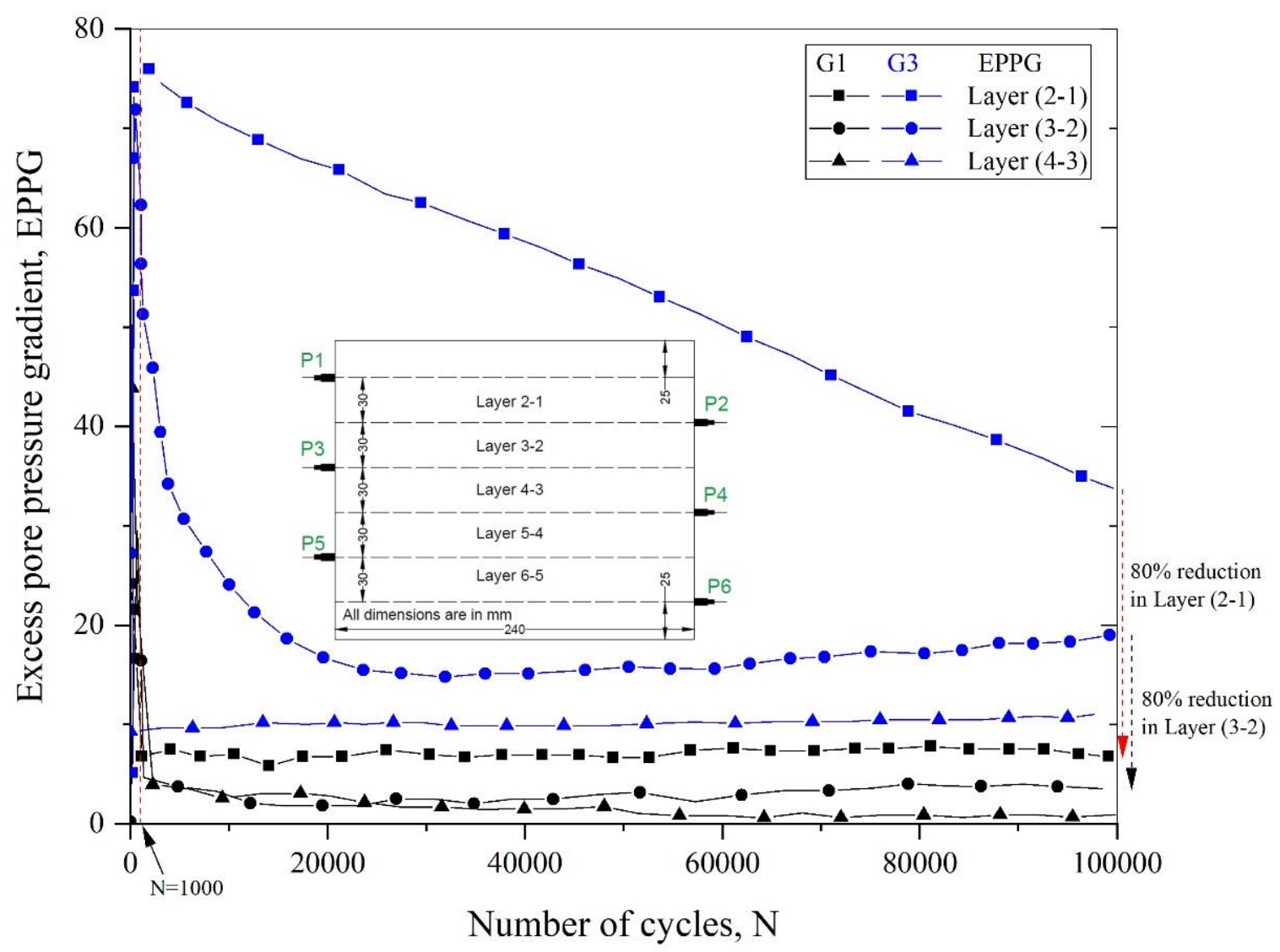



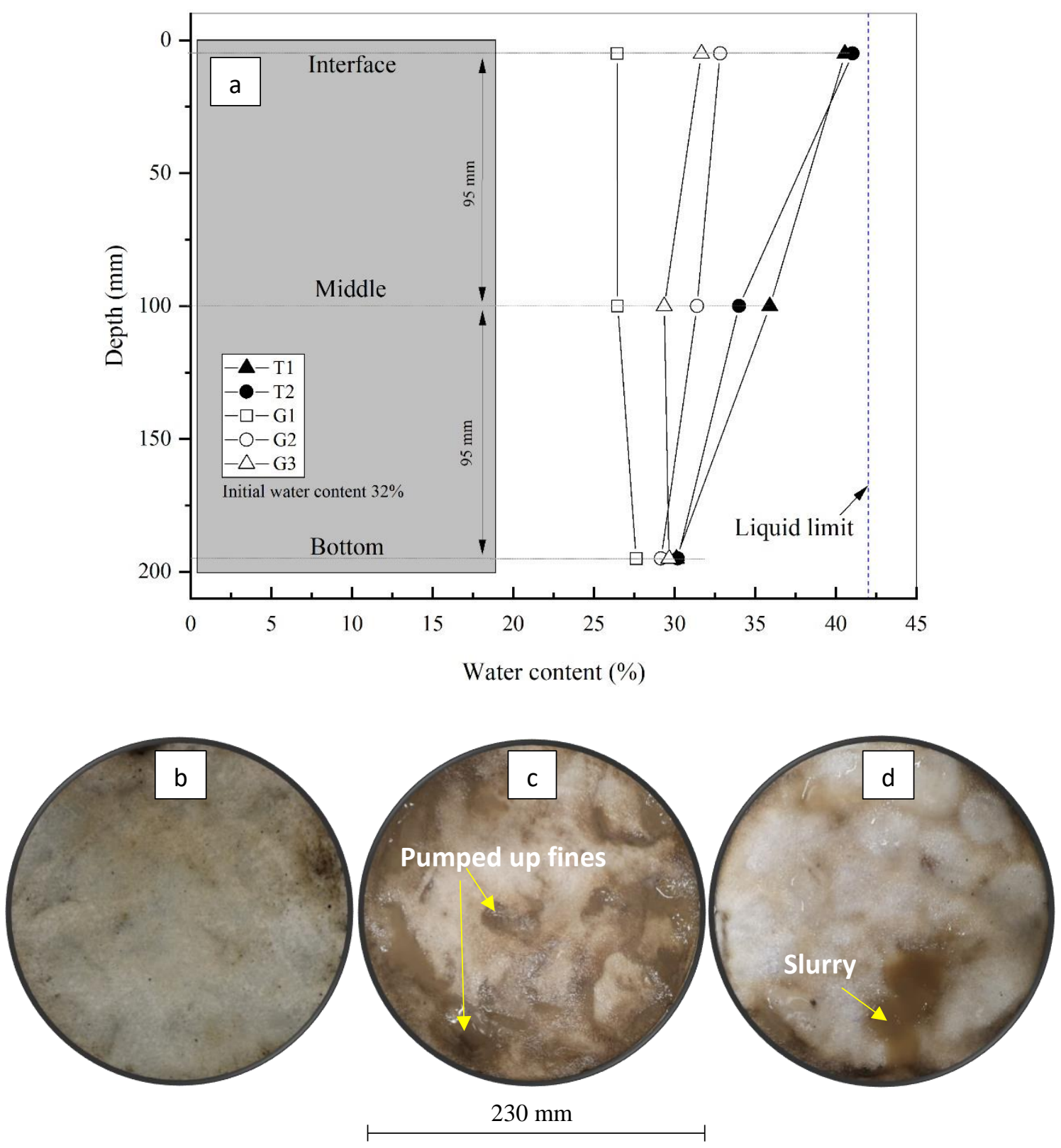


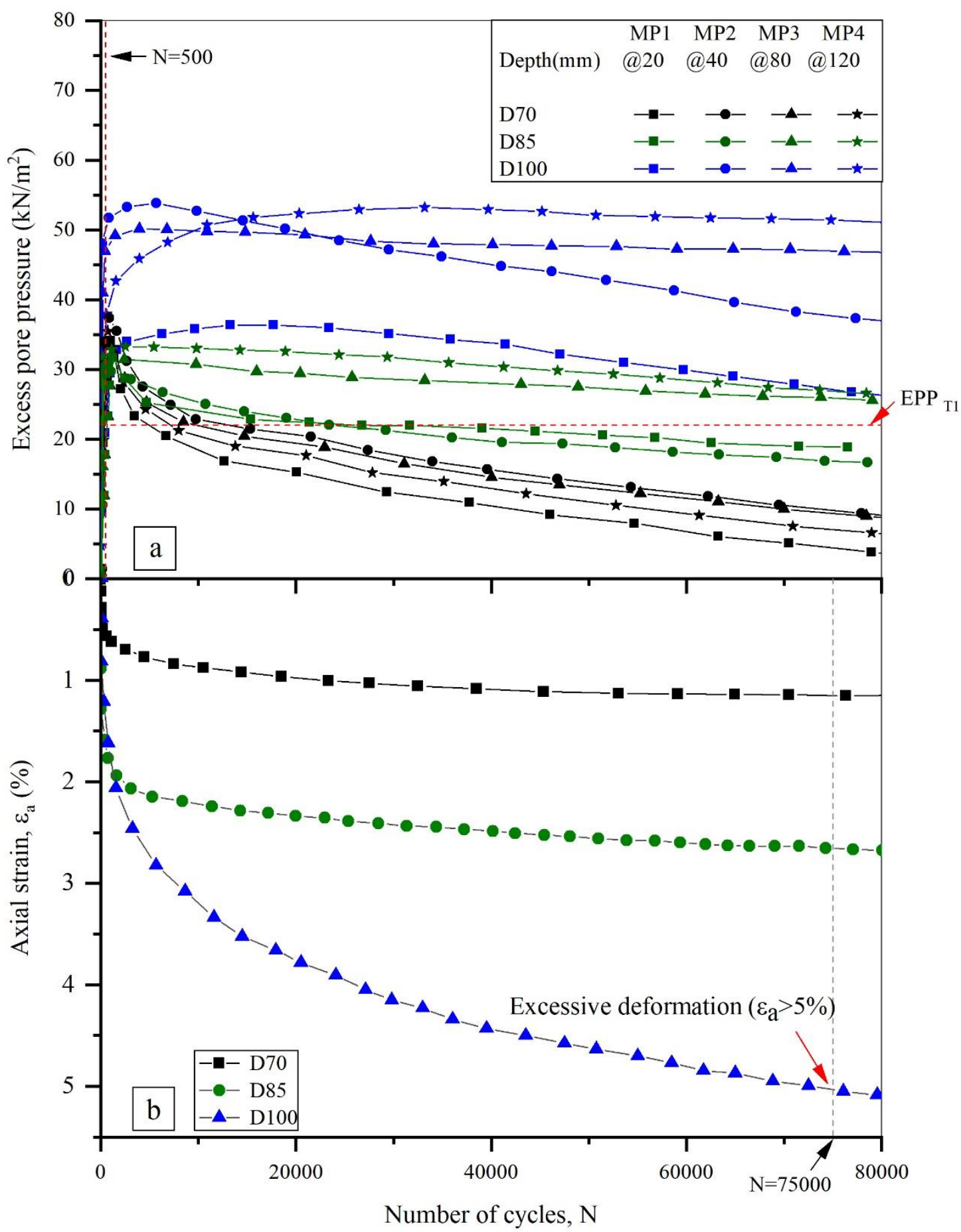

Figure 10: (a) Excess pore pressures, and (b) Axial strains under different cyclic deviatoric stresses 


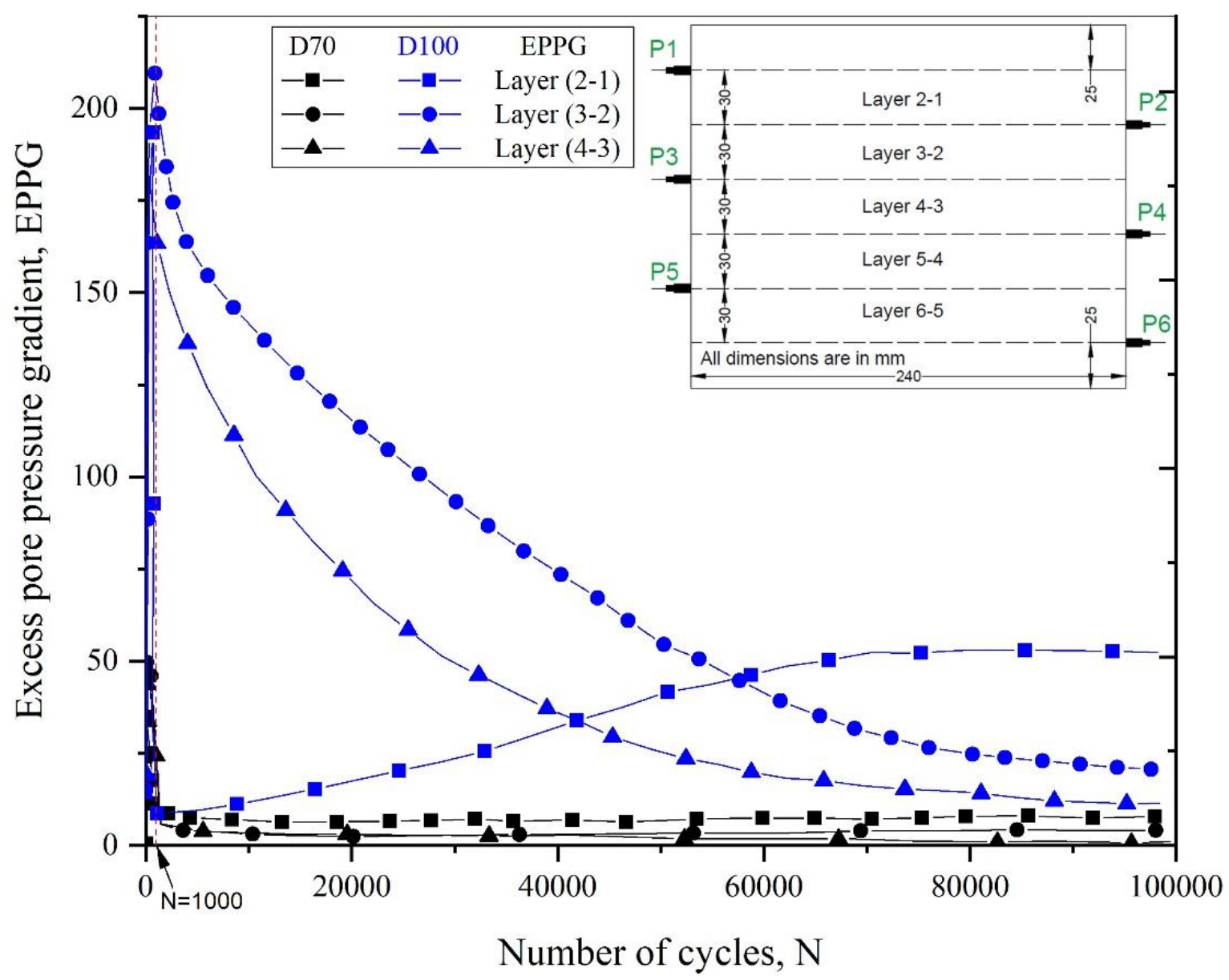

690

691

Figure 11: Excess pore pressure gradients for Tests D70 and D100

692

693

694

695

696

697

698

699

700

701 

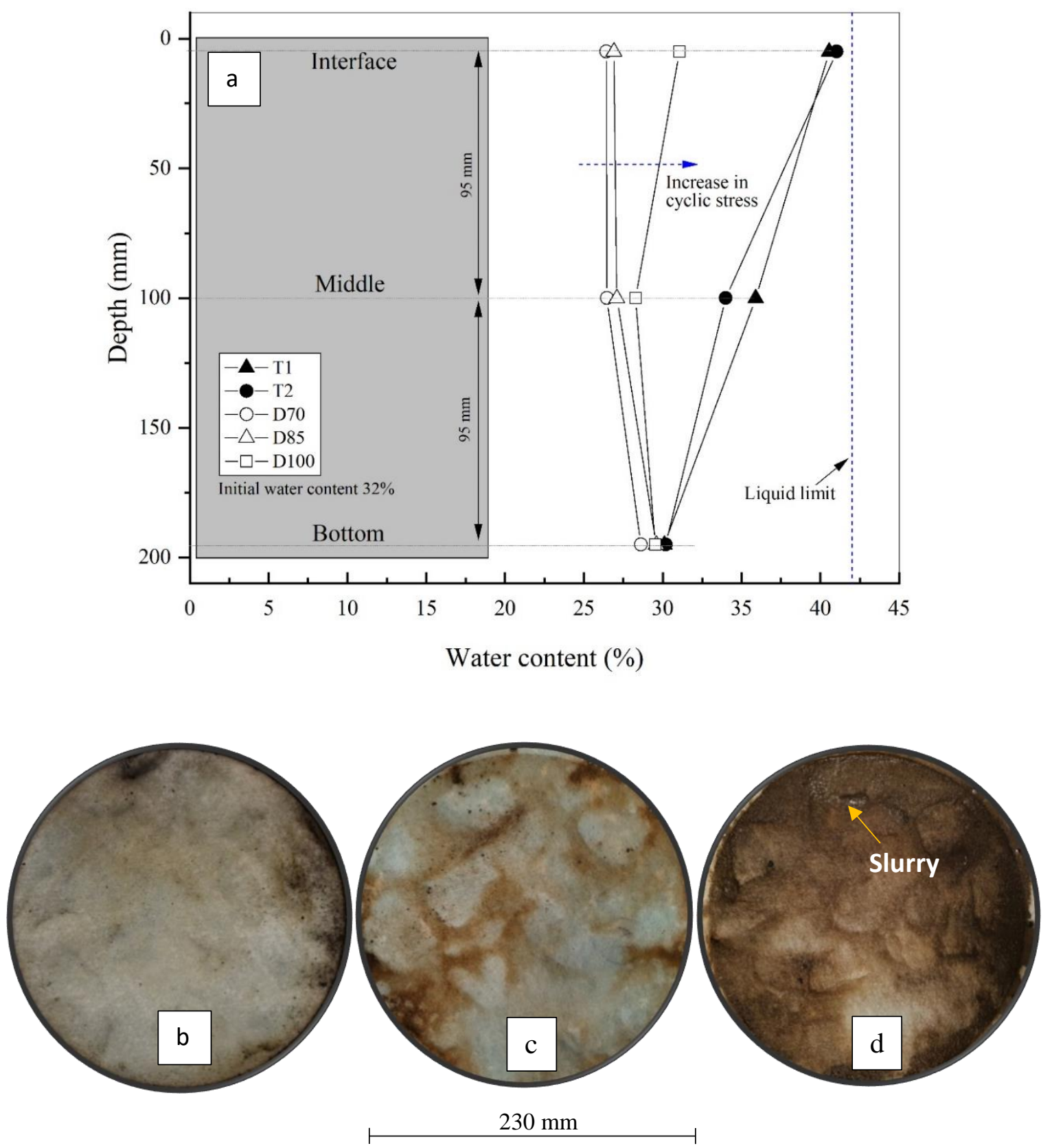

702

Figure 12: (a) Water contents after 100,000 cycles, Photos of tested G1 (magnification $=0.209 x$ ) after 100,000 cycles (b) Test D70 (c) Test D85, and (c) Test D100 

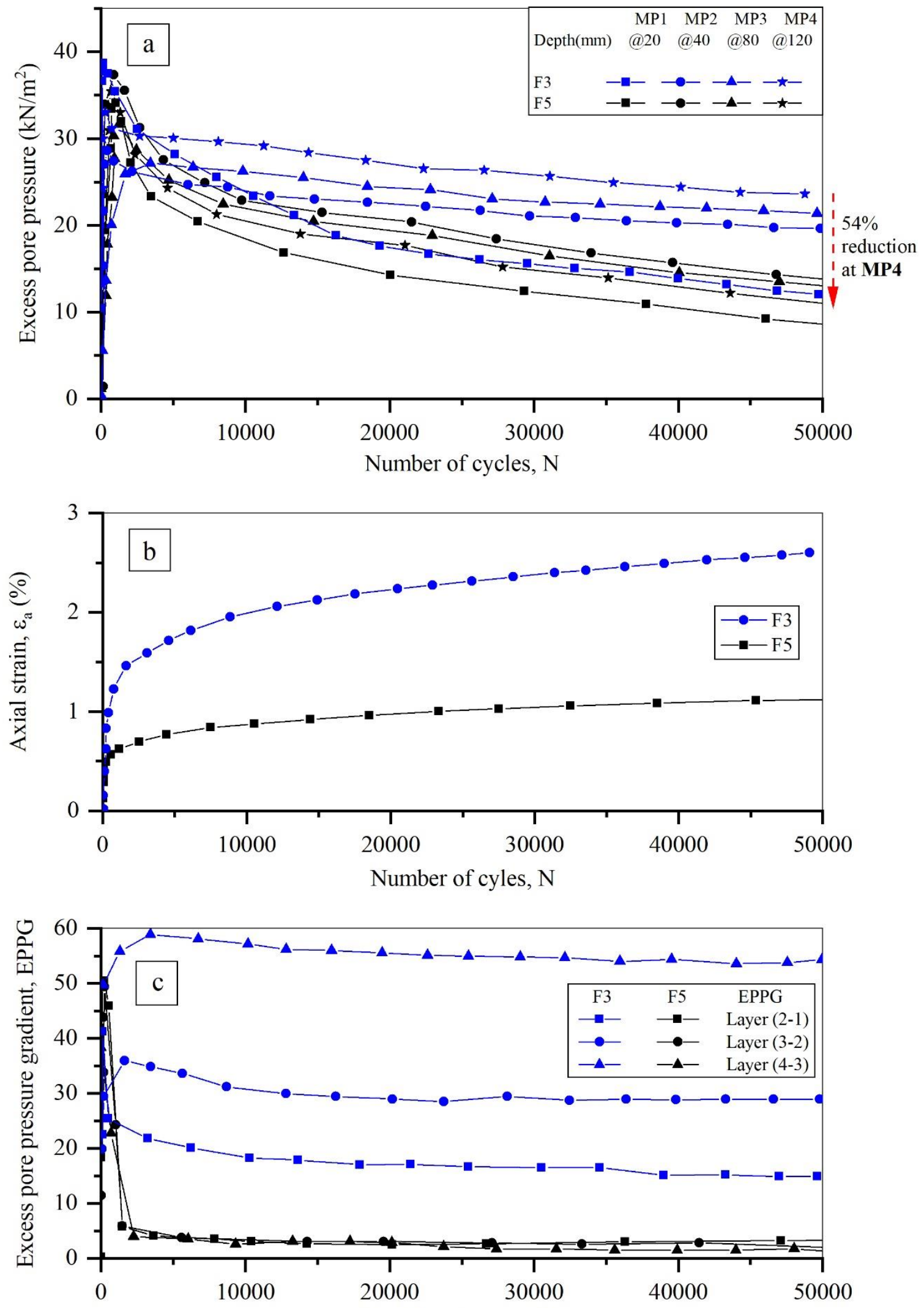

Figure 13: Tests F3 and F5 (a) Excess pore pressures, (b) Axial strains, and (c) Excess pore pressure

gradients 

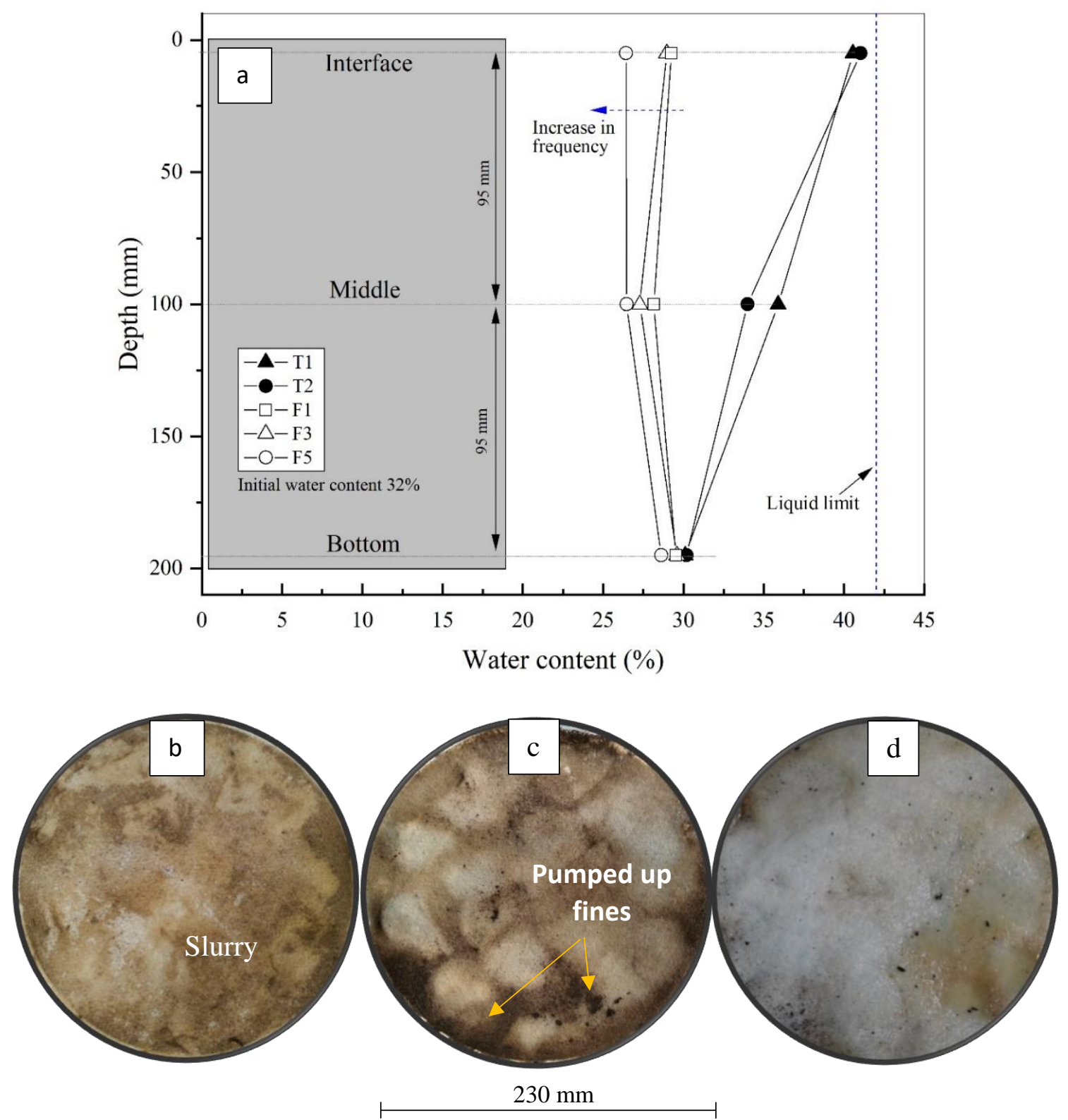

Figure 14: (a) Water contents after 50,000 cycles, Photos of tested G1 (magnification $=0.209 x$ ) after 50,000 cycles (b) Test F1 (c) Test F3, and (c) Test F5 